\title{
Redescription of the taxon Tricorygnatha (Ephemeroptera, Tricorytbus s.l.) based on new findings in Africa and Indonesia
}

\author{
Переописание таксона Tricorygnatha (Ephemeroptera, \\ Tricorythus s.l.) на основе новых находок \\ в Африке и Индонезии
}

\author{
Nikita J. Kluge \\ Н.Ю. КАюге
}

\begin{abstract}
Department of Entomology, Saint-Petersburg State University, Universitetskaya nab., 7/9, Saint-Petersburg 199034, Russia. E-mail: kluge@FK13889.spb.edu. Website: http://www.insecta.bio.pu.ru

Кафедра энтомологии, биолого-почвенный факультет, С.-Петербургский государственный университет, Университетская наб., $7 /$ 8, С.-Петербург 199034, Россия.
\end{abstract}

KEY WORDS: Tricorygnatha, Tricorythidae, Tricorythus, Sparsorythus, new species, new combination.

КЛЮЧЕВЫЕ СЛОВА: Tricorygnatha, Tricorythidae, Tricorythus, Sparsorythus, новые виды, новые комбинации.

ABSTRACT. General characteristic of the taxon Tricorygnatha is reviewed. This taxon can be regarded as a single genus Tricorythus s.l. The type species of Tricorythus - T. varicauda - is revealed for the first time since it was collected by naturalists who accompanied the army of Napoleon in Egypt. Larva, subimago, imago and egg of this species, associated by rearing, are described. Larvula of Tricorygnatha is described for the first time. Additional characteristic of T. tinctus is given, basing on new material from Uganda. A new species T. exophthalmus sp.n. from Uganda is described, basing on larvae and a reared male subimago. A new species Tricorythus (Sparsorythus) celebensis sp.n. from Sulawesi is described, basing on larvae, reared male imagoes and female adults. Several non-described species are reported from Africa and Java.

РЕЗЮМЕ. Пересмотрена общая характеристика таксона Tricorygnatha, который можно считать единым родом Tricorythus s.l. Его типовой вид - T. varicauda - выявлен впервые с тех пор, как он был собран натуралистами, сопровождавшими армию Наполеона в Египте. Описываются личинка, субимаго, имаго и яйца этого вида, ассоциированные путём выведения. Впервые описывается ларвула Tricorygnatha. На основании нового материала из Уганды дается дополнительная характеристика $T$. tinctus. По личинкам и выведенному самцу субимаго из Уганды описывается новый вид $T$. exophthalmus sp.n. По личинкам, выведенным самцам имаго и выведенным взрослым самкам с Сулавеси описывается новый вид Tricorythus (Sparsorythus) celebensis sp.n. Из Африки и Явы указываются несколько неописанных видов.

\section{Introduction}

The first specimens of Tricorythus Eaton, 1868 reported in literature, were collected in 1798 by scientists who accompanied army of Napoleon Bonaparte in Egypt; these specimens are figured in the "Description de l'Egypte". Luxuriously printed plates of this edition contain beautiful and accurate drawings of numerous animal species. Among them, there are 4 species of mayflies (Insectes-Névroptères, Pl. II, Figs 4-8), for which Savigny [1827: 443] gave brief comment without any species names or even numbers; they were determined as belonging to the genus Ephemera Linnaeus, 1758 (which corresponds to the modern order Ephemeroptera). The species in Fig. 4 (male imago belonging to Baetis Leach, 1815 s.l.) and in Fig. 8 (female imago probably belonging to Cloeon Leach, 1815) are not identified; they were only mentioned by Pictet [1843:272] as belonging to the genus Cloe Burmeister, 1839 (which corresponds to the modern family Baetidae). The species in Fig. 5 was described as Palingenia savignyi Pictet, 1843 (recently placed to the genus Ephoron Williamson, 1802). The species in the Figs 6-7 (male and female imagoes) was described as Caenis varicauda Pictet, 1843.

Pictet [1843-1845] based his description of Caenis varicauda only on the male imaginal specimens examined by him; geographical origin of these specimens is known only as upper parts of Egypt. These specimens were received by Pictet from the Museum of Vienna and later returned there [Ulmer, 1916, 1921]. The drawing made by Pictet [1845: P1. 43, Fig. 5], unlike the drawings in the "Description de l'Egypte", is inaccurate.

Eaton [1868] established a new genus Tricorythus and designated Caenis varicauda as its type species. He 
did not examine any specimens of $T$. varicauda, but only repeated its original description [Eaton, 18831888]. These days the family-group name Tricorythidae Lestage, 1942 (with the type genus Tricorythus) is used for a large taxon which unites about 240 nominal species arranged into about 50 nominal genera. The widest taxon with typified name formed from Tricorythus, is Tricorythus/fg1 sensu Kluge, 2000, or PANTRICORYTHI Kluge, 2004; its subordinated taxa form no less than 6 hierarchical levels [Kluge, 2004].

However, the type species of Tricorythus remains to be poorly known. Ulmer [1916] described and figured genitals of the type specimen of Tricorythus varicauda. This description is the only one which allows to distinguish this species from others. Most taxa of tricorythids, as well as of mayflies in general, are characterized mainly by larval structure. As the larva of the type species was unknown, the nomenclature of many tricorythid taxa was only provisional.

In the present paper, the type species of Tricorythus is redescribed based on new material collected by the author in Uganda in 2007 - male and female adults reared from larvae. These specimens of $T$. varicauda are the first ones reported since the Napoleon's expedition to Egypt.

Examination of the new material shows that the traditional understanding of systematic position of the type species of Tricorythus is correct. It belongs to a taxon known as the family Tricorythidae in the narrowest sense, or subfamily Tricorythinae of some authors, or the genus Tricorythus in wide sense; in order to avoid confusion connected with typified names, this taxon got also an additional non-typified circumscriptional name Tricorygnatha Kluge, 2004.

For some representatives of Tricorygnatha from Madagascar, there were established separate genera Madecassorythus Elouard et Oliarinony, 1997, Spinirythus Elouard et Oliarinony, 1998a and Ranorythus Elouard et Oliarinony, 1997, and even separate subfamilies Madecassorythinae and Ranorythinae [Elouard \& Oliarinony, 1997; Oliarinony \& Elouard, 1997; Oliarinony, Elouard \& Raberiaka, 1998a; Oliarinony, Sartori \& Elouard, 2000]. All Asian representatives of Tricorygnatha were attributed to the separate genus Sparsorythus Sroka et Soldan, 2008, which is characterized by loss of maxillary palp and, most probably, represents a holophyletic taxon [Sroka \& Soldán, 2008]. At the same time, African and some Madagascar species remain to be accepted within a single genus Tricorythus. Recently Barber-James [2008] suggests to divide African species of Tricorygnatha into three genera: Tricorythus (= varicauda group), "new genus" (= discolor group) and another "new genus" (= tinctus group). Probably, these groups are natural, but at the present time imagoes and larvae are associated for a few species only, thus it is difficult to draw boundaries between these taxa. Until a comprehensive natural classification of Tricorygnatha is not elaborated, it is expedient to regard all Tricorygnatha as belonging to a single genus Tricorythus s.l., and to regard Madecassorythus, Spinirythus, Ranorythus and Sparsorythus as its subgenera.
All material examined, including the holotypes of Tricorythus exophthalmus sp.n. and T. (Sparsorythus) celebensis sp.n., is deposited in the Zoological institute of Russian Academy of Sciences (in Saint-Petersburg), temporarily locate in Department of Entomology of Saint-Petersburg State University.

In the lists of material examined, the following arbitrary signs are used: L - larva; S - subimago; I imago; A - adult (subimago unable for further molt); LS-IO' - male imago reared from larva, with larval and subimaginal exuviae; L-S $\sigma^{7}$ - male subimago reared from larva, with larval exuviae; L/S $\sigma^{7}$ — male subimago extracted from mature larva; S-I $\sigma^{\top}$ — male imago reared from subimago, with subimaginal exuviae; L-A + - female adult reared from larva, with larval exuviae.

\section{Tricorygnatha}

Circumscriptional name: TRICORYgnatha Kluge, 2004.

Hierarchical name: Tricorythus/fg4 ( ${ }^{2}$ sine Vietnamella, Melanemerella, Teloganodes; ${ }^{3}$ sine Leptohyphes; ${ }^{4}$ sine Ephemerythus, Dicercomyzon, Machadorythuis; incl. Madecassorythus, Spinirythus, Ranorythus, Sparsorythus) [f: Tricorythidae Lestage, 1942; g: Tricorythus Eaton, 1868, type species: Caenis varicauda Pictet, 1843 (by original designation)].

Possible ranking names: subfamily Tricorythinae Lestage, 1942, or genus Tricorythus Eaton, 1868 (s.1.)

Systematic position. Tricorygnatha (or Tricorythus/fg4) belongs to the following successively subordinated taxa: Euplectoptera (or Ephemeroptera s.str.) - Anteritorna Bidentiseta — Furcatergaliae — Ephemerella/fg1 (or Ephemerelloidea) - Pantricorythi (or Tricorythus/fg1) Tricoryptera (or Tricorythus/fg2) - Afrotricorythi (or Tricorythus/fg3) [Kluge, 2004].

Larvula. Basing on a single larvula of Tricorythus tinctus (see below and Figs 31-34), the following characteristic of this stage can be given. Mandibles are enlarged, with long setae (as in older larva - see below). Maxilla (Fig. 33) has one long denticulate apical canine (while in older larva it is lost) and one dentiseta (as in older larva - see below); maxillary palp is absent (while older larva of the same species has long maxillary palp). Hypopharynx lacks apical incision (Fig. 32) (unlike older larva). Mentum, glossae and paraglossae are fused into a large plate (Fig. 32) (as in older larva - see below). Each claw has two subapical rows of fine denticles and has no denticles in proximal part (Fig. 34) (unlike older larva - see below). Tergalii VII appear earlier than others and have a form of long cylindrical soft processes (Fig. 31) (while older larva of the same species lacks tergalii VII - see below).

Larva. Mandibles are enlarged, with regular row of long setae on outer margin; lateral end of this row is curved toward ventral side of mandible. Initial shape of mandible is shown in Fig. 4; in T. tinctus and related species mandibles undergo further modification (see below and Fig. 38). Maxilla has unique structure, uniform in all species (Fig. 2): flat, truncate in such a manner that its apical margin is formed by expansion of initial inner (median) margin, and its apical-lateral angle corresponds to initial apical-median angle; apical canines are lost (being retained in larvula — see above); a single dentiseta (instead of two dentisetae characteristic for Bidentiseta) is long and slender, situated near apical-lateral angle; setae of initial inner-dorsal row are as long as dentiseta, and form a regular row on apical margin; each seta of this row has such basal articulation, which allows it to turn dorsally or distally only [Kluge, 2004: Fig. 97B]; initial inner-ventral row of setae is lost; ventral side, besides the subapical field of 
dense ordered setae (characteristic for Ephemerella/fg1), bears a regular transverse row of long setae; each seta of this row has such basal articulation, which allows it to turn ventrally or distally only [Kluge, 2004: Fig. 97C]. Maxillary palp is unusually long, with slender, long, arched $1^{\text {st }}$ and $2^{\text {nd }}$ segments and small $3^{\text {rd }}$ segment (while muscles inside the maxillary palp are lost, as in all Ephemerella/fg1); among Tricorygnatha, only in Sparsorythus maxillary palp is lost (larvula has no maxillary palp - see above). Labium has unique structure, uniform in all species (Fig. 1): submentum is strongly shortened; paraglossae (which in all Ephemerella/fg1 are fused with mentum), glossae and mentum are completely fused together, forming an integral semicircular plate; ventrally this plate bears a pair of fields of long setae; dorsally it has a concavity, whose outline repeats shape of hypopharynx; hypopharynx is inserted into this concavity. Labial palp retains all three segments; $2^{\text {nd }}$ segment is especially long, arched, with two regular rows of long filtering setae: one row consists of especially long setae and goes along outer margin; another row goes along inner margin; $3^{\text {rd }}$ segment is short.

Fore protoptera (which in all Ephemerella/fg1 are fused by means of mesial plate) are fused up to their apices, so that free margin of mesial plate between their apices is not expressed (Figs 12, 35, 52, 77, 86-89). Thanks to this, mesial plate has triangular shape. In course of transformation to subimago, hypoderm of the mesial plate can form a separate unpaired triangular plate with small apical cleft (Figs 35, 52) (instead of a pair of plumidia in some other Ephemerella/ fg1); during subsequent transformation to subimago, this plate can be dissolved, so in winged stages it can be absent. Remainders of this plate can be retained in adult as a pair of soft projections by sides of the tip of scutellum; in most specimens examined, these projections are so small, that do not extend behind tip of scutellum, but in selected specimens of $T$. (S.) celebensis sp.n. (both among male subimagoes and female adults) they are longer, having a form of plumidia.

Fore legs are larger than middle legs, hind legs are the largest (Figs 7-9, 39-41, 60-63, 71-73, 86-89). Femora have rows of stout setae characteristic for Pantricorythi: on fore femur anterior (dorsal) surface is crossed by a transverse row; middle and hind femora have longitudinal rows on outer (hind) margin and on inner (fore) margin. Tibiae of all legs lack patella-tibial suture. Claws have uniform apomorphic structure in all species (Fig. 10): row of denticles on inner margin consists of 2 denticles only: a small denticle at base of sclerotized part of claw and a larger denticle close to it (sometimes there is one more very small proximal denticle Figs 50-51); besides these two inner denticles, there are two subapical side denticles - one subapical denticle on each side of claw. Larvula has quite different structure of claws (see above and Fig. 34).

Abdomen has peculiar apomorphic structure (Figs 1314): it is not flattened (unlike most Ephemerella/fg1), relatively high, with lateral sides belonging to terga; on segments II-VII these lateral sides are concave, so that by sides of abdomen there is a pair of elongate-oval, shallow tergalial cavities; tergalii are attached inside these cavities and can be inserted in them; tergalii are attached laterally (unlike most other Ephemerella/fg1, whose tergalii are attached dorsally); segments VIII-IX, unlike others, are nearly cylindrical, without lateral ridges or laterally expanded flattened lobes and without posterolateral spines (unlike most other mayflies). Tergalii I are lost (as in all Tricoryptera). Tergalii II-VI retain all lobes peculiar for Ephemerella/fg1 - dorsal lamellate lobe and ventral bifurcate lobe with numerous lateral processes; unlike some other Ephemerella/fg1, in Tricorygnatha these processes are not widened, filiform (Figs 15-16). Size of tergalii gradually decreases from tergalii II to VI, so that lamella of tergalius II is 1.6-1.8 times longer and wider than lamella of tergalius VI (Figs 13, 86-89). At the same time, tergalii II are non-operculate and move synchronously with next ones (unlike Ephemerythus, Leptohyphes/fg1, and some others). Tergalii VII are often lost; only in some species of Sparsorythus they are retained as small vestiges. Unlike larva with developed tergalii, yang larvula has tergalii VII, which appear before tergalii of other pairs (see above and Fig. 31); thanks to this, the loss of tergalii VII in mature larva is reversible. Caudalii (cerci and paracercus) of male larva are thickened in proximal part, unlike caudalii of female, which have usual form (the same in Ephemerythus, Leptohyphes/ fg1 and Caenoptera).

Imago and subimago. Molt from subimago to imago takes place in male only; female adult has no subimaginal/ imaginal molt. This fact is proven at least for the species discussed below - T. varicauda, T. tinctus, T. sp. I, T. discolor, T. (Sparsorythus) celebensis sp.n., T. ?jacobsoni and $T$. sp. B. Non-molting female adult differs from true imago by presence of subimaginal microtrichiae on wings and body; at the same time, it differs from true subimago by absence of imaginal cuticle inside. Among imaginal cuticular formations, the most well-recognizable are hooked claws (the hind claw of each leg), because their pointed tips do not coincide with tips of subimaginal claws; on translucent slides imaginal hooked claws are always well visible on middle and hind legs of male subimago (Figs 24, 51, 67) and never exist in female adult (Fig. 22).

Eyes of male are either large and have different facets on dorsal and ventral portions, or small as in female. Mesothorax has following modifications (Figs 27, 42, 80): On mesonotum lateroparapsidal suture is not curved laterally (unlike initial for Ephemerella/fg1), but convergents with medioparapsidal suture; sublateroscutum has a transverse interscutal suture (unlike other Afrotricorythi; the same in Leptohyphes/ $\mathrm{fg} 1$ and Caenoptera). Infrascutellum is interrupted medially, scutellum is more or less enlarged, with enlarged lateral impressions (the same in other Tricoryptera, also in Teloganodes/fg1 and Caenoptera). About plumidia - see above.

Fore wing has Y-shape cubital fork (characteristic for Afrotricorythi), lacks marginal intercalaries (Figs 25-26). Marginal setae (which are always present in subimago) are present in imago as well. Hind wings are absent. At rest, wings are spread by sides or somewhat turned up (as in Leptohyphes/fg1, Caenoptera and some others, but unlike Dicercomyzon and Ephemerythus, whose wings are raised up, as in most mayflies).

Fore legs of male imago are not elongate (unlike most Ephemeroptera), subequal to middle and hind legs. On all legs $1^{\text {st }}$ tarsal segment is completely fused with $2^{\text {nd }}$ segment, without suture between them; on middle and hind legs $1^{\text {st }}$ segment (which initially for Furcatergaliae is fused with tibia and shortened) on its outer side is secondarily distinctly separated from tibia; thus, tarsi are 4-segmented. On fore legs of male claws in imago are blunt, in subimago ephemeropteroid; on other legs claws are ephemeropteroid both in imago and subimago (Figs 23-24, 50-51, 66-67); exception is made by Madecassorythus and Ranorythus, whose claws of male imaginal fore leg are said to be ephemeropteroid.

Distal segment of gonostylus (which in Ephemerella/fg1 is single, instead of two distal segments initial for Ephemeroptera) is lost; proximal segment is long and distinctly separated from the $2^{\text {nd }}$ segment (that is characteristic for Pantricorythi); so gonostylus is 2-segmented (Figs 17, 44, 68, 81). 
Sexual dimorphism. Some sexual features of male, which are initially present in Ephemeroptera, are lost in Tricorygnatha: Fore legs of male imago and subimago are not elongate, being equal to for legs of female. Protogonostyli of male larva are not expressed (see below), so posterior margin of sternum IX is identical in male and female larvae.

At the same time, Tricorygnatha have some secondary sexual characters: Unlike male, female subimago does not molt to imago and retains subimaginal features (microtrichiae on wings, ephemeropteroid claw of fore leg). Wings of male imago and subimago are usually wider in proximal part, than wings of female adult (Figs 25-26) (the same in some Leptohyphes/fg1 and Caenoptera). Caudalii of male larva are thickened in proximal part (Figs 86-89); in male subimago caudalii grow: just after larval/subimaginal molt they are as short as in larva, later become very long; caudalii of male imago are extremely long, nearly 3 times longer than the body; unlike male, in female caudalii of larva have usual form, and in adult stage are shorter than in most mayflies (shorter than the body); besides Tricorygnatha, the same sexual dimorphism in caudalii structure exists in Ephemerythus, Leptohyphes/fg1 and Caenoptera.

In some taxa within Tricorygnatha, larva has unusual sexual dimorphism in shape of pronotum (Figs 52-53): in male larva fore margin of pronotum is expanded medially as a semicircular flap and overlaps hind part of head; in contrast, in female larva median part of fore margin is straight. Like other larval sexual characters, this one is mostly expressed in last larval instar; in younger male larva median expansion of fore margin of pronotum is less prominent (Fig. 54). Unlike larvae, adults have no sexual dimorphism in shape of fore margin of pronotum: their pronotum has concave anterior margin, as in other mayflies (Fig. 70). Such larval sexual dimorphism, which has no any connection with imaginal sexual dimorphism, has not been found in other mayflies. Among Tricorygnatha, the sexual dimorphism in shape of larval pronotum is found in $T$. discolor (see below), $T$. exophthalmus sp.n. (see below and Figs 52-54), Tricorythus sp. R (see below), T. (Spinirythus) martini (examined by me), known species of Madecassorythus [Oliarinony, Sartori \& Elouard, 2000], T. (Sparsorythus) dongnai and T. (Sparsorythus) bifurcatus (personal communication by P. Sroka). In some species sexual dimorphism in shape of larval pronotum is completely absent; these are: $T$. varicauda (see below), $T$. tinctus (see below), Tricorythus sp. N (see below) and $T$. (Sparsorythus) celebensis sp.n. (see below). The fact that this feature varies among species of the holophyletic taxon Sparsorythus, testifies about its mosaic pattern. Probably, the sexual dimorphism in shape of larval pronotum correlates with large male eyes (see below).

In some taxa within Tricorygnatha, eyes of male are large and divided into a lower portion with black facets and an upper portion with lighter facets. As in other mayflies with large male eyes, this character is expressed both in adults (Fig. 70) and in larvae of late instars (Figs 52-53, 88). Large male eyes are found in T. discolor (see below), T. exophthalmus sp.n. (see below), Tricorythus sp. R (see below), $T$. (Sparsorythus) bifurcatus, T. (Sparsorythus) jacobsoni, T. (Sparsorythus) dongnai, all known species of Madecassorythus, Spinirythus and Ranorythus. In some species eyes of male are as small as in female; among species examined, these are: T. varicauda (see below), T. tinctus (see below), Tricorythus sp. N (see below), Tricorythus sp. S (see below) and T. (Sparsorythus) celebensis sp.n. (see below). Judging by pattern of this character among Tricoryptera and other mayflies, enlarged male eyes can be either a symplesiomor- phy with most mayflies, or an apomorphic reversion. The fact that this feature varies among species of the holophyletic taxon Sparsorythus, testifies about its mosaic pattern. Probably, among Tricorygnatha large male eyes correlate with the sexual dimorphism in shape of larval pronotum (see above).

In T. exophthalmus sp.n., mature male larva has fore tarsus swollen apically (Fig. 60). Male subimago has fore claws enlarged (Fig. 66); before molt from larva to subimago, the enlarged subimaginal claws locate inside the swelling on larval tarsus. Unlike male, female larva has tarsus nonwidened (Fig. 61); probably, female adult has fore claws non-enlarged. The same sexual dimorphism in shape of larval tarsus and size of adult claws is found in selected non-related species of Oligoneuriidae [Kluge, 2004: Fig. 43D; Kluge, 2007: Fig.6].

Development of male genitals. In male larva protogonostyli (i.e., external projections corresponding to imaginal gonostyli) are not expressed: areas of sternum IX, corresponding to gonostyli, are brought together apically and fused; between them locates an area of sternum IX, corresponding to median part of styliger; thanks to its position, it always has triangular shape (Fig. 84). In course of metamorphosis, posterior margin of imaginal styliger can either retain the larval triangular shape (Fig. 44), or undergoes degeneration and becomes less prominent (Figs 85).

Distribution. Tropical areas of the Old World - Ethiopian and Oriental regions.

Taxa subordinated. At the present time, when a comprehensive natural classification of Tricorygnatha is not elaborated, it is expedient to regard all Tricorygnatha as belonging to a single genus Tricorythus Eaton, 1868 (s.1.) (type species: Caenis varicauda Pictet, 1843), and to regard Madecassorythus, Spinirythus, Ranorythus and Sparsorythus as subgenera of Tricorythus.

The taxa Madecassorythus Elouard \& Oliarinony, 1997 (type species: Madecassorythus hertui Elouard \& Oliarinony, 1997), Spinirythus Oliarinony \& Elouard (in Oliarinony, Elouard \& Raberiaka) 1998 (type species S. martini Oliarinony \& Elouard, 1998) and Ranorythus Oliarinony \& Elouard, 1997 (type species $R$. violettae Oliarinony \& Elouard, 1997) were established for 9 species from Madagascar. They can be accepted as subgenera of Tricorythus, with the following species: Tricorythus (Madecassorythus) hertui (Elouard \& Oliarinony, 1997) comb.n., Tricorythus (Madecassorythus) linae (Elouard \& Oliarinony, 1997) comb.n., Tricorythus (Madecassorythus) ramanankasinae (Oliarinony \& Elouard in Elouard \& Oliarinony, 1997) comb.n., Tricorythus (Madecassorythus) raphaeli (Oliarinony \& Sartori in Oliarinony, Sartori \& Elouard, 2000) comb.n., Tricorythus (Spinirythus) colasi (Elouard \& Oliarinony in Oliarinony, Elouard \& Raberiaka, 1998) comb.n., Tricorythus (Spinirythus) martini (Oliarinony \& Elouard in Oliarinony, Elouard \& Raberiaka, 1998) comb.n., Tricorythus (Spinirythus) rosae (Oliarinony \& Raberiaka in Oliarinony, Elouard \& Raberiaka, 1998) comb.n., Tricorythus (Ranorythus) longrandi (Oliarinony \& Elouard, 1997) comb.n., Tricorythus (Ranorythus) violettae (Oliarinony \& Elouard, 1997) comb.n.

The taxon Sparsorythus Sroka \& Soldan, 2008 (type species: Sparsorythus bifurcatus Sroka \& Soldan, 2008) is characterized by a single autapomorphy — loss of maxillary palp. As larvula of Tricorygnatha has no maxillary palp (see above), and in all cases maxillary palp is muscle-less, the loss of maxillary palp can be repeatable. However, it is probable that Sparsorythus is a holophyletic taxon, because all species of Sparsorythus, whose male imagoes are known, have similar shape of genitals. Sparsorythus includes all Asian species 
of Tricorygnatha. This taxon can be accepted as a subgenus of the genus Tricorythus, with the following species: Tricorythus (Sparsorythus) jacobsoni Ulmer, 1913, Tricorythus (Sparsorythus) bifurcatus (Sroka \& Soldan, 2008) comb.n.,
Tricorythus (Sparsorythus) ceylonicus (Sroka \& Soldan, 2008) comb.n., Tricorythus (Sparsorythus) dongnai (Sroka \& Soldan, 2008) comb.n., Tricorythus (Sparsorythus) gracilis (Sroka \& Soldan, 2008) comb.n.; Tricorythus (Sparsorythus)

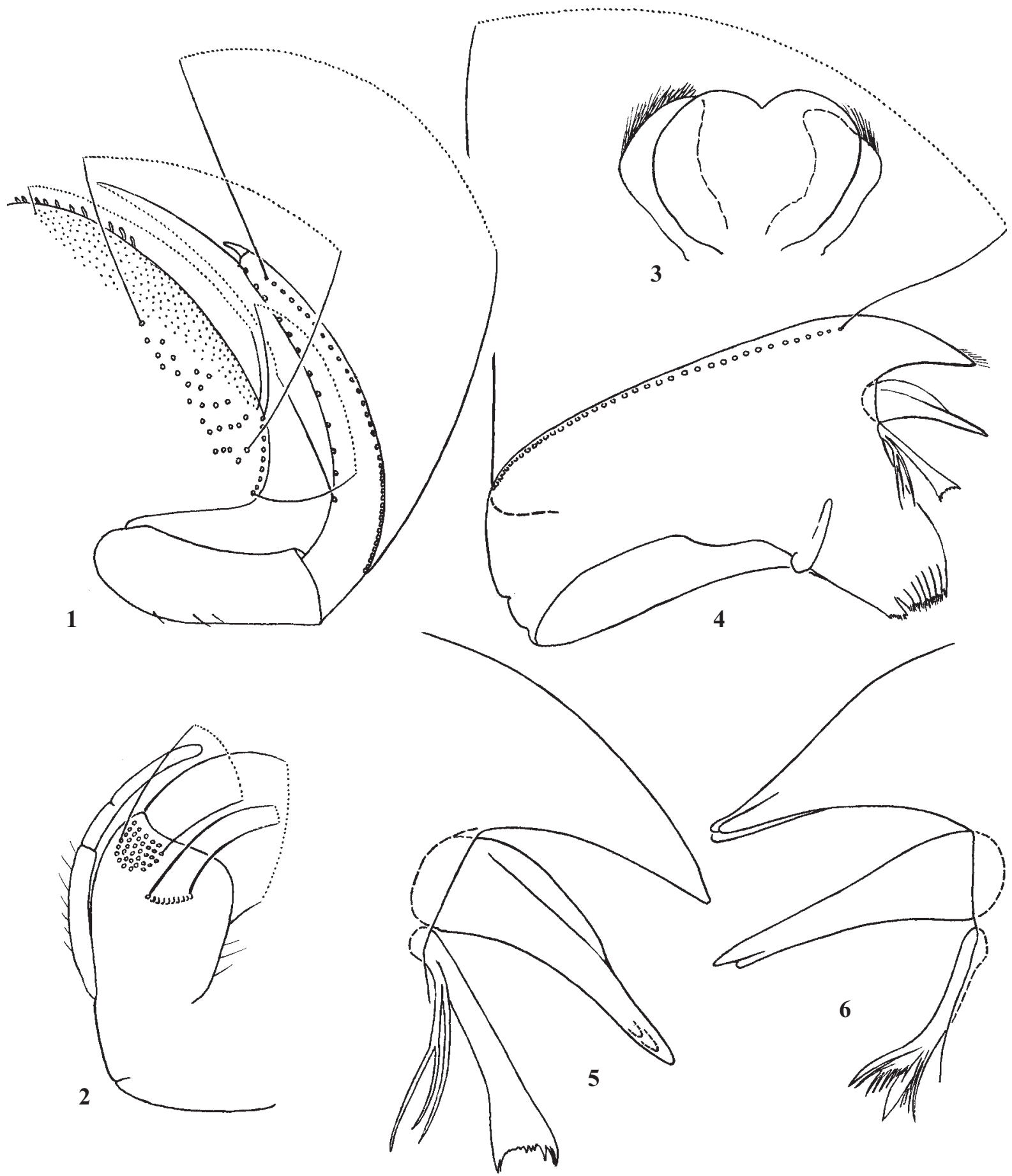

Figs 1-6. Tricorythus varicauda, larval mouthparts (most of long setae not shown, areas occupied by them shown by dotted lines): 1 left half of labium, ventral view; 2 - right maxilla, ventral view; 3 - hypopharynx and superlinguae, ventral view; 4 - left mandible, dorsal view (interrupted lines show continuation of setal row on ventral side and hidden base of kinetodontium); 5-6 - incisor, kinetodontium and prostheca of left and right mandibles.

Рис. 1-6. Tricorythus varicauda, ротовые части личинки (большая часть длинных щетинок не показана, занимаемые ими области показаны точечными линиями): 1 — левая половина нижней губы, вентрально; 2 — правая максилла, вентрально; 3 — гипофаринкс и суперлингвы, вентрально; 4 - левая мандибула, дорсально (прерывистыми линиями показаны продолжение ряда щетинок на вентральной стороне и скрытое основание кинетодонта); 5-6 - инцизор, кинетодонт и простека левой и правой мандибул. 
grandis (Sroka \& Soldan, 2008) comb.n., Tricorythus (Sparsorythus) multilabecularis (Sroka \& Soldan, 2008) comb.n. and Tricorythus (Sparsorythus) celebensis sp.n. (see below).

Phylogenetic classification of other species is not elaborated. They can be either united into a plesiomorphon subgenus Tricorythus, or regarded as unplaced members of the genus Tricorythus s.l. These are: African species, for which both imagoes and larvae are known $-T$. varicauda (see below), T. tinctus (see below); T. discolor (see below), $T$. exophthalmus sp.n. (see below); African species known as imagoes only $-T$. abyssinicus Ulmer, 1930, T. longus Ulmer, 1916, T. latus Ulmer, 1916, T. lanceolatus Kimmins, 1960; species from Madagascar, described as imagoes by Oliarinony, Elouard \& Raberiaka [1998b]: T. ambinintsoae, $T$. fyae, $T$. goodmani, $T$. jeanna, $T$. pierrei, $T$. rolandi, $T$. sylvestri, $T$. variabili and $T$. vulgaris.

African species fuscata Navás, 1936 [Neurocaenis], poincinsi Navás, 1926 [Tricorythus] and reticulatus Barnard, 1932 [Tricorythus] were described as female adults only, so their systematic position is doubtful.

The genus Neurocaenis Navás, 1936 with type species $N$. fuscata Navás, 1936 was characterized by number of crossveins greater than in Tricorythus [Demoulin, 1954]. Some species were moved by these or that authors from Tricorythus to Neurocaenis and back. As number of crossveins is variable, it was suggested to regard Neurocaenis as a junior synonym of Tricorythus [Oliarinony, Elouard \& Raberiaka, 1998b]. The type species of Neurocaenis is known as female adult only [Demoulin, 1954], so its true systematic position is unclear; its wing venation is similar to that of the type species of Tricorythus (as in Fig. 25).

The subgenus Tricorythurus Lestage, 1942 was established for a single species T. latus Ulmer, 1916 and was characterized by 3 -segmented gonostyli, as they were described by Ulmer [1916]. Demoulin [1954] demonstrated that actually $T$. latus has 2-segmented gonostyli and synonymized Tricorythurus with Tricorythus.

\section{Tricorythus varicauda (Pictet, 1843)}

Figs 1-14, 17-30, 86

Ephemera: Savigny, 1826-1827: Fig.6-7 (male and female imagoes).

Caenis varicauda Pictet, 1843-1845 (male imago).

Tricorythus varicauda: Eaton, 1868, 1871, 1883-1888 (male imago, after Pictet 1843-1845).

Tricorythus varicauda: Ulmer, 1816 (male imago, syntype).

MATERIAL. UGANDA, Kasese district, Kiburara, river Nyamagasan, 20.VIII.2007, coll. N. Kluge: 1 L-S-I $\sigma^{\top}, 2$ L-S $\sigma^{\top}, 2$ $\mathrm{L}-\mathrm{A}+, 1 \mathrm{~S} \sigma^{\top}, 17$ larvae. RWANDA: riv. Runange, entre Kigali et Bjumba, 31.XII.1987, coll. P. Landolt \& D. Studemann: 1 larva; pref. Bueare, comm. Ngoma, pont sur Mukura, $8 \mathrm{~km}$ de Butare sur route Burundfi, 21.XII.1987, coll. P. Landolt \& D. Studemann: 1 larva TANZANIA, Iringa, 18.III.1963, coll. M.T. Gillies: $9 \sigma^{7}$ imagoes.

Larva. Cuticular COLORATION: Whole cuticle is lightbrownish, nearly unicolor, without maculation.

HyPODERMAL COLORATION: Head and thorax dorsally have blackish maculae, thorax ventrally light. Each femur has two wide longitudinal blackish stripes separated by narrower longitudinal blank Fig. 86). Protoptera in all instars are dark: hypoderm of wing membrane is uniformly dark brown, veins are slightly lighter, poorly visible. Abdominal terga are dark, sterna lighter. Tergalii have dorsal lamellate lobe gray with margins colorless, ventral lobe gray. Caudalii are either uniformly light, or have alternating dark and light segments in proximal part.

SHAPE AND SETATION: Frons and clypeus lack projections (Fig. 12). Eyes of male are as small as in female (Figs 12, 86).
Mandibles have incisors not elongated, curved (Figs 4-6); left prostheca is symmetrically widened apically, with 3 bristle-like processes at base (Fig. 5); right prostheca has shape usual for Tricorygnatha (Fig. 6). Number of setae in transverse row on ventral side of maxilla is 9-12 (in last larval instar). Maxillary palps are long (Fig. 2) (unlike Sparsorythus).

Pronotum has moderate width; anterolateral angles are rounded and only slightly projected forward; anterior margin between them in both sexes is straight; mesonotum is not shortened (Figs 12, 86). Legs as in Figs 7-9: Femora have moderate width. Stout setae on femora (which form rows characteristic for Pantricorythi) are elongate, apically widened and blunt, situated irregularly: on fore femur transverse row of stout setae is irregular, not continuous on outer margin; on middle and hind femora row of stout setae along outer margin is irregular; on middle femur irregularly situated stout setae form a field resembling a part of the transverse row of fore leg. Fore tarsus in male larva is not widened, the same as in female larva.

On abdominal terga, tergalial cavities (see diagnosis of Tricorygnatha) are not bordered by long setae. Denticles on hind margins of abdominal terga are irregular, weak, elongate, most of them parallel-sided - either pointed, or blunt, or terminating by several points (Fig. 11). Vestiges of tergalii VII are absent. Protopenis is unusually long (longer than in other species examined), reaches hind margin of sternum IX, somewhat bent ventrally (Figs 13, 20, 21) (see below).

Subimago, male. CUTICULAR COLORATION AND TEXTURE: Cuticle of mesonotum is light brown with blanks of composite branched shape; densely covered with microtrichiae except for blanks. Cuticle of pterothorax has sclerites light brown and membranes colorless. On mesonotum antelateroparapsidal suture and anterolateral scutal costa are darkest; sublateroscutum dark; lateroscutum dark, with small blank; posterior scutal protuberances are lightest (Fig. 27). Microtrichiae densely cover all areas of mesonotum except for posterior scutal protuberances; cuticle of posterior scutal protuberances bears sparse microtrichiae and net-like relief (see Table). Basal plate of wing has distinctly outlined subimaginal sclerite of characteristic shape and brown color (Fig. 27). Cuticle of legs is partly colorless, with intensive contrasting longitudinal stripes: each femur has four stripes along outer and inner margins; each tibia has brown basal part and stripe along outer margin; each tarsus in most part is brown. Cuticle of abdominal terga and sterna is light brown, with small, contrasting, paired blanks: each tergum II-IX has a pair of small submedian blanks near anterior margin, a pair of small sublateral blanks and one or two pairs of lateral blanks; each sternum II-VIII has submedian blanks in form of a pair of stripes diverging from anterior margin and a pair of dots behind them and two pairs of small lateral blanks; sternum IX has a T-shape blank on anterior margin and midline. Gonostyli have dark band at joining of first and second segment. Cuticle of caudalii is colorless.

HyPODERMAL COLORATION: As in imago.

Imago, male. HYPODERMAL AND CUTICULAR COLORATION: Head and prothorax have intensive dark gray hypodermal maculation. Mesonotum has cuticle light brown, lateral part of posterior scutal protuberance and lateroscutum lighter; longitudinal gray hypodermal stripes are visible through cuticle. Cuticle of mesolpeura is nearly colorless, through it gray hypodermal maculae are visible. On ventral side of pterothorax, the pair of episterna and the pair of furcasternal protuberances have cuticle light brown; median areas between them (i.e., basisternum and furcasternal impression) 
have cuticle colorless and hypoderm gray. Legs have intensive dark gray hypodermal maculation. Wings are gray. Abdominal terga and sterna look nearly unicolor thanks to intensive dark gray hypodermal pigmentation. Styliger, gonostyli and penis also have gray hypodermal pigmentation.
Caudalii are nearly uniformly gray, with slightly expressed alternating of darker and lighter segments.

SHAPE: Eyes are small, stalked (Fig. 28). Mesonotum has lateroparapsidal suture strongly curved (Fig. 27). Genitals as in Figs 17-19: Sternum IX has well expressed dark

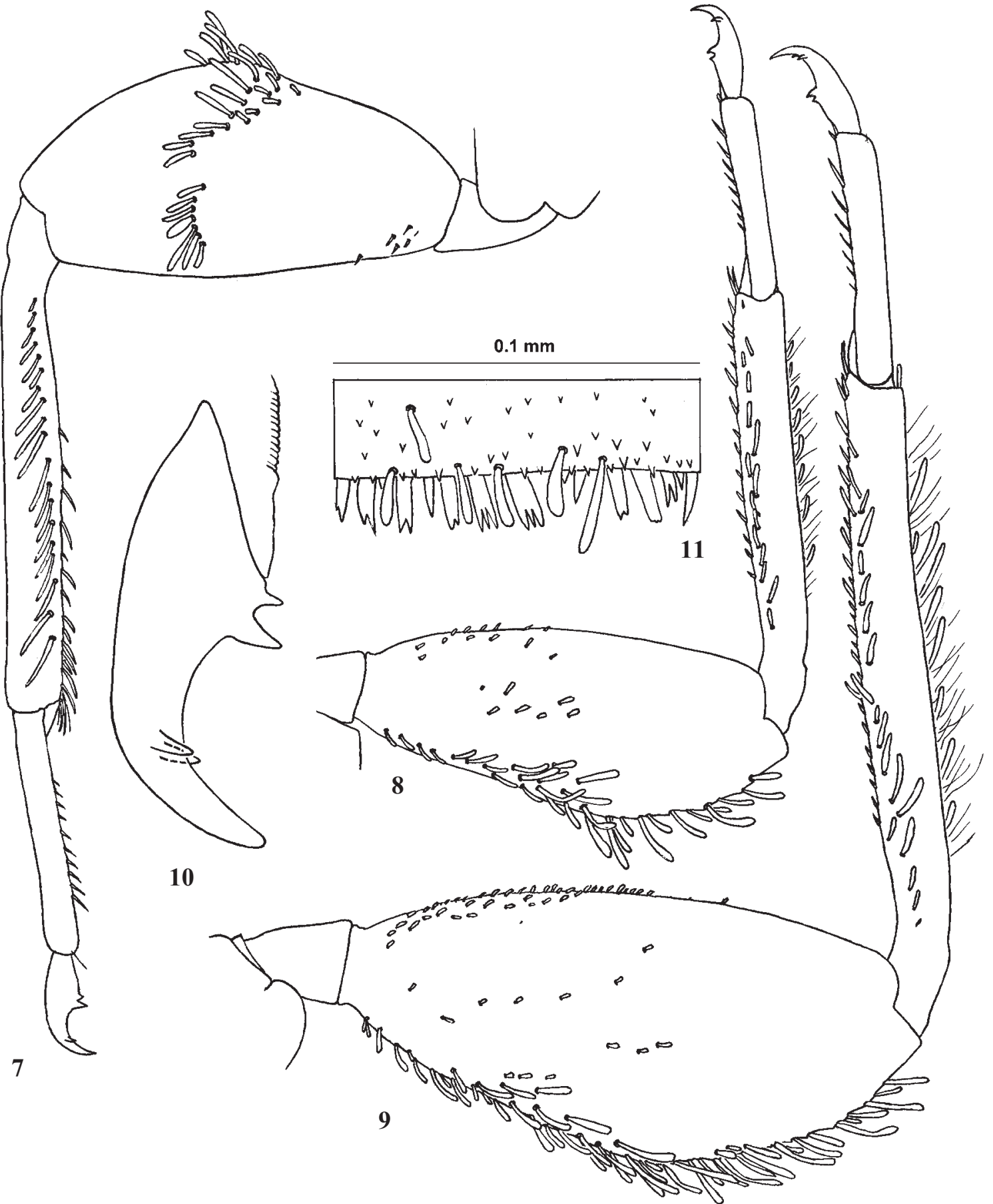

Figs 7-11. Tricorythus varicauda, larva: 7-9 — right fore, middle and hind legs of last instar male larva, dorsal (anterior) view; 10 claw; 11 - hind margin of abdominal tergum VII

Рис. 7-11. Tricorythus varicauda, личинка: 7-9 - правые передняя, средняя и задняя ноги личинки самца последнего возраста, дорсально (спереди); 10 - коготок; 11 - задний край VII тергита брюшка. 
lines, which border areas of attachment of sterno-styligeral muscles; these lines are longitudinal, nearly straight and parallel-sided. Styliger has shape of a narrow ark: short, with length equal in middle and by sides, medially far extended from sternum IX. Penis is narrow, widened at the middle, bifurcates beginning from the middle, with apices brought together; in lateral view penis is bent S-shaped, apices roundish.

Development of male genitals. Larval protopenis is unusually long (Fig. 20), that correlates with long penis of adult (Fig. 17). In this respect $T$. varicauda differs from other species examined, whose size, shape and proportions of larval protopenis are not correlated with size, shape and proportions of adult penis (see below).
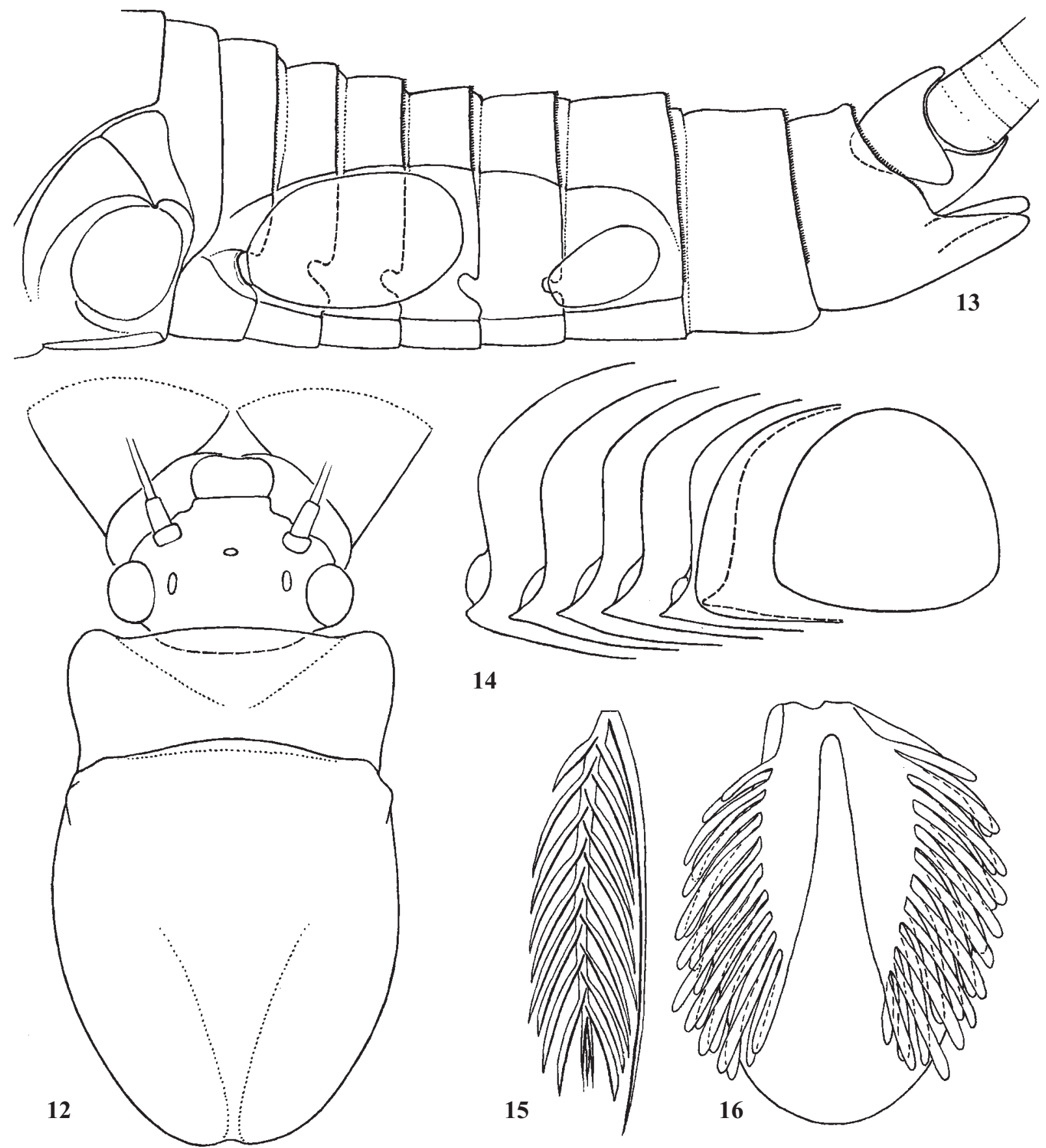

14

Figs 12-16: 12-14 - Tricorythus varicauda, larva: 12 - head, pronotum and mesonotum; 13 - abdomen, lateral view (tergalii IIIV taken away); 14 — view from behind to left half of each of abdominal segments II-VIII; $15-16$ — Tricorythus sp. N: 15 — tergalius, side view; 16 - the same, ventral view.

Рис. 12-16: 12-14 - Tricorythus varicauda, личинка: 12 - голова, пронотум и мезонотум; 13 - брюшко, латерально (тергалии III-V удалены); 14 — вид сзади на левую половину каждого из II-VIII сегментов брюшка; 15-16 — Tricorythus sp. N: 15 — тергалия, сбоку; 16 - то же, вентрально. 

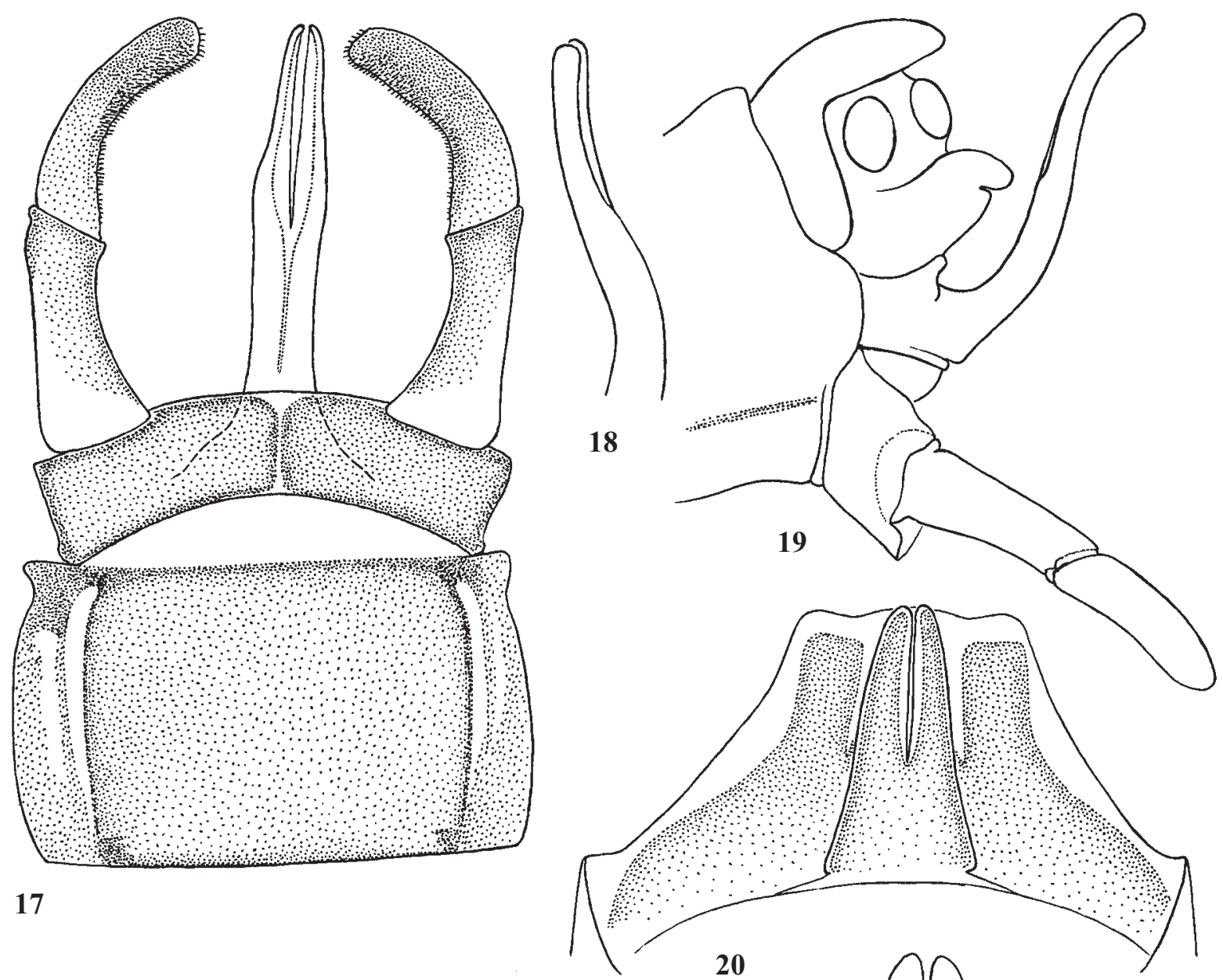

17

20

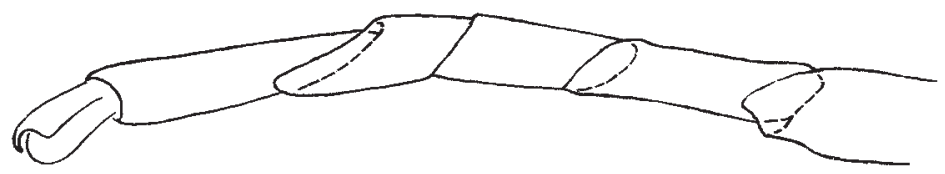

22

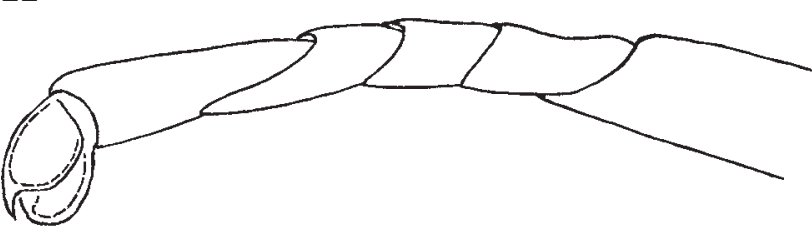

23

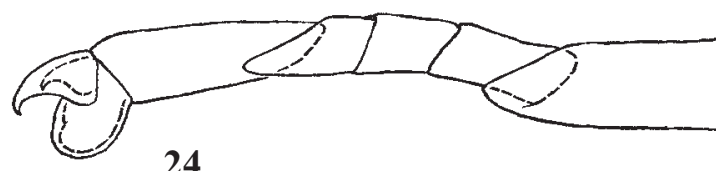

$-1$ 1

Figs 17-24. Tricorythus varicauda: 17 - genitals of male imago, ventral view (gray hypodermal pigmentation shown by dots); 18 penis of subimago, lateral view; 19 - tip of abdomen of male imago, lateral view; 20 - genital buds of last instar male larva, dorsal view (larval cuticle shown by integral lines, tissues by dots); 21 - genital buds of male larva molting to subimago, dorsal view (subimaginal cuticle shown by interrupted line); 22 - tarsus of fore leg of female adult; $23-24$ - tarsus of fore and middle legs of male subimago (imaginal claws shown by interrupted lines; 17, 18, 20-24 - specimens from Uganda; 19 - specimen from Tanzania).

Pис. 17-24. Tricorythus varicauda: 17 - гениталии самца имаго, вентрально (пунктировкой показана серая гиподермальная пигментация); 18 - пенис субимаго, латерально; 19 - вершина брюшка самца имаго, латерально; 20 - зачатки гениталий у личинки самца последнего возраста, дорсально (личиночная кутикула показана сплошной линией, ткани пунктированы); 21 зачатки гениталий личинки самца, линяющей на субимаго, дорсально (субимагинальная кутикула показана прерывистой линией); 22 - лапка передней ноги взрослой самки; 23-24 - лапка передней и средней ноги самца субимаго (имагинальные коготки показаны прерывистыми линиями); 17, 18, 20-24 - экземпляры из Уганды; 19 - экземпляр из Танзании). 


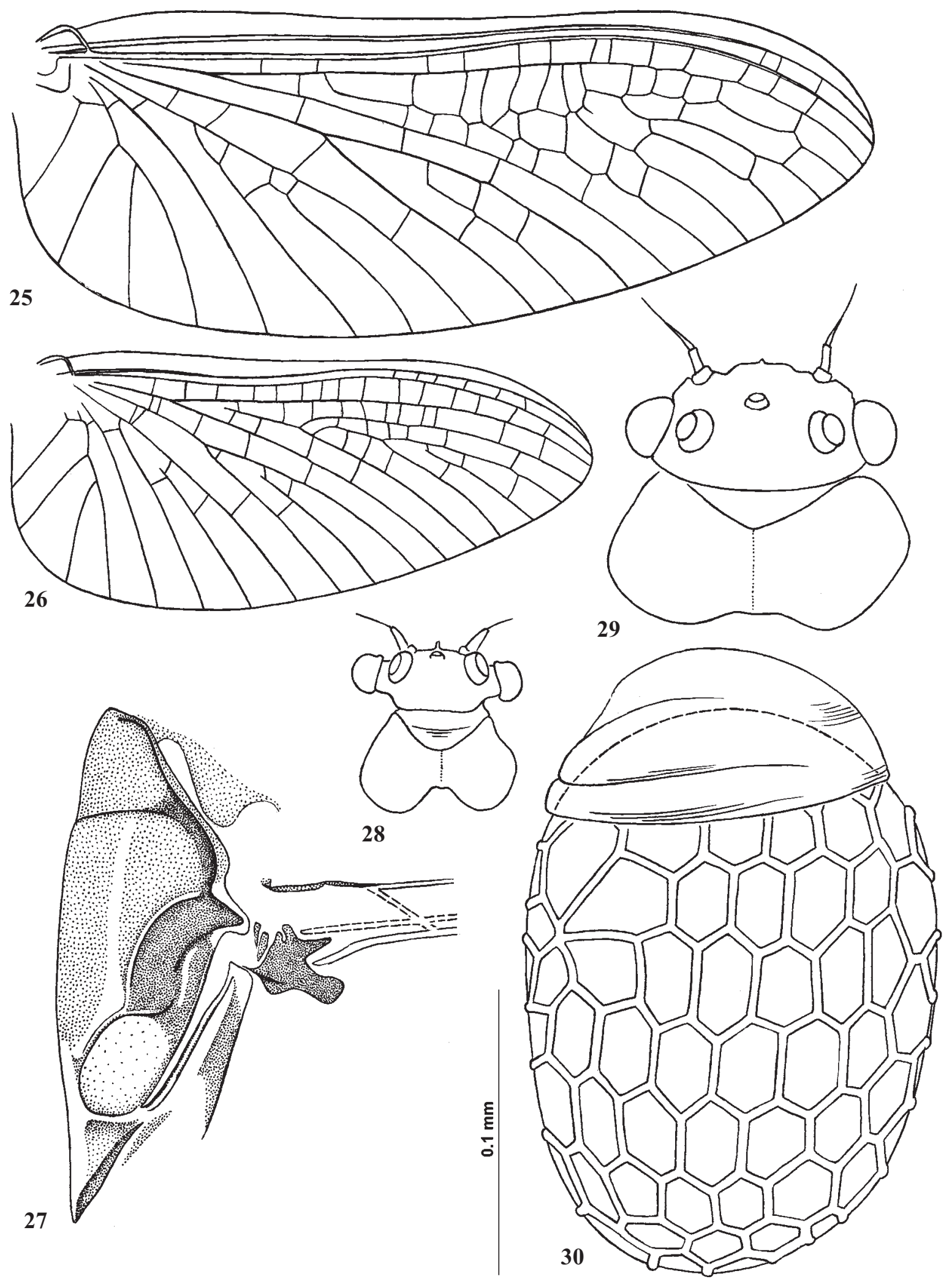

Figs 25-30. Tricorythus varicauda: 25 — wing of female adult (marginal setae not shown); 26 — the same, male imago; 27 - right half of subimaginal exuviae of male mesonotum (brown cuticular pigmentation shown by dots); 28 — head and pronotum of male imago; 29 the same, female adult; 30 - egg.

Рис. 25-30. Tricorythus varicauda: 25 — крыло взрослой самки (краевые щетинки не показаны); 26 - то же, самец имаго; 27 правая половина субимагинального экзувия мезонотума самца (пунктировкой показана бурая кутикулярная пигментация); 28 голова и пронотум самца имаго; 29 - то же, взрослой самки; 30 - яйцо. 
Adult, female. Head as in Fig. 29. Cuticular coloration as in male subimago. Unlike male subimago, cuticle of posterior scutal protuberances lacks microtrichiae and has net-like relief only (see Table). Hypodermal coloration as in male. Femora are not wide, have the same width as in male subimago.

Egg. Pale yellowish, with silver polar cap. Surface with relief in a form of regular convex net with large cells. Polar cap, formed by spirally coiled threads, is nearly as wide as egg, has somewhat irregular shape (Fig. 30).

DIMENSION. Wing length (and approximate body length) of male $5 \mathrm{~mm}$, of female $8 \mathrm{~mm}$.

EMERGENCE. Larvae were collected in submountain part of the river Nyamagasan with fast current and stony bottom. Larvae molted to subimagoes at the beginning of darkness. Male subimago molted to imago during the same night. The fact that females have no subimaginal/imaginal molt, is supported by the fact that claws of female subimago do not contain imaginal claws (Fig. 22); claws of male subimago contain imaginal claws during whole subimaginal development (Fig. 24) and earlier, before larval/subimaginal molt.

Tricorythus tinctus Kimmins, 1956

Figs $31-49,87$

Tricorythus tinctus: Kimmins, 1956 (male and female imago). Tricorythus tinctus: Corbet, 1960 (larva).

MATERIAL. UGANDA, river Nile at Bujagali Falls, 6.VII.2007, coll. N. Kluge: 16 S-IO', $198 \mathrm{IO}^{7}, 187 \mathrm{SO}^{7}$, 30 larvae, 1 larvula.

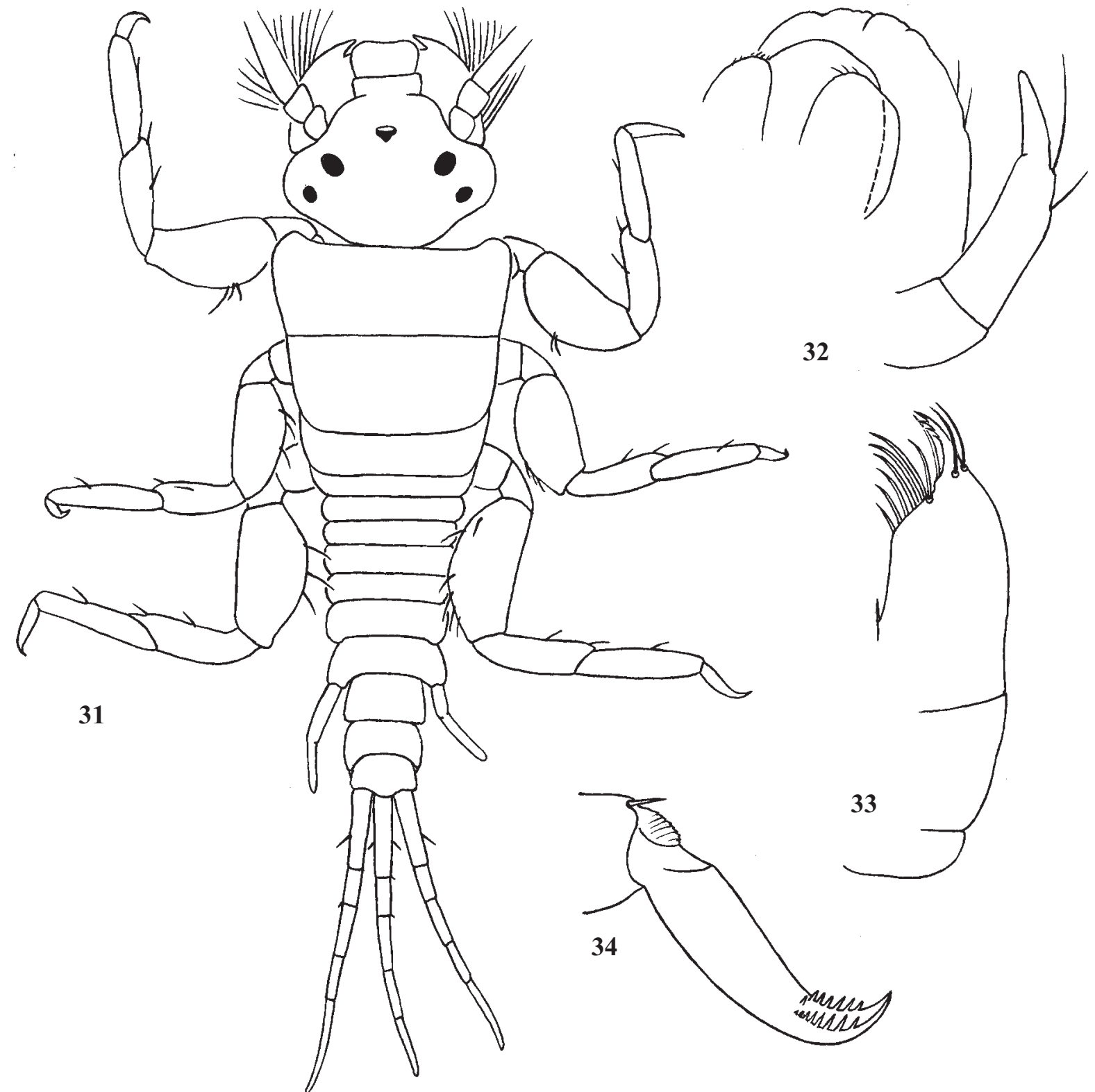

Figs 31-34. Tricorythus tinctus, larvula: 31 - habitus, dorsal view; 32 - half of labium, hypopharynx and superlinguae, dorsal view; 33 - maxilla, ventral view; 34 - claw, ventral view.

Рис. 31-34. Tricorythus tinctus, ларвула: 31 - внешний вид, дорсально; 32 - половина нижней губы, гипофаринкс и суперлингвы, дорсально; 33 - максилла, вентрально; 34 - коготок, вентрально. 
Larva. Cuticular coloration: Whole cuticle is lightbrownish, nearly unicolor, without maculation.

Hypodermal coloration: Head, thorax and abdomen dorsally have dark gray and purplish maculae; thorax and abdomen are ventrally light, whitish. Each femur has dark gray maculae and contrasting whitish blanks; dorsal side is at most part dark, with a blank at base (especially large on fore femur), two or three blanks at middle and a blank at apex (Fig. 87); ventral side is at most part whitish, with smaller dark maculae. Each tibia is dark at most part, light at base and at apex. Each tarsus is dark at proximal part, light at distal part; claws are light. Protoptera of immature larva (at several latest instars) have hypoderm of wing membrane colored by brown; this color is darkest at basal and costal parts of protopteron and lightest along tornoapical margin, gradually changing color from darker to lighter areas (Fig. 87); all veins are light and well visible (unlike sp. N); wings of adult have no this brown color, so in mature larva with developing subimaginal wings, color of protoptera becomes lighter (unlike most mayflies, whose protoptera become darker). Tergalii have dorsal lamellate lobe gray with margins colorless, ventral bifurcate lobe is gray. Caudalii are entirely light.

SHAPE AND SETATION: Head has paired projections on frons and clypeus (Fig. 37). Eyes of male are as small as in female (Figs 35, 87). On each mandible, incisor projects into a long pointed tusk, which is straight in dorsal view (Figs 38, 87) and slightly curved dorsally; when mandibles are pressed together, their tusks are crossed. Left prostheca is asymmetrically widened apically, with many bristle-like processes at base; right prostheca has shape usual for Tricorygnatha. Number of setae in transverse row on ventral side of maxilla is $8-12$ (in last larval instar). Maxillary palps are long (unlike Sparsorythus).

Pronotum is wide; antero-lateral angles are strongly projected forward; anterior margin between them in both sexes is straight; mesonotum has fore protoptera short (Figs 35, 87).
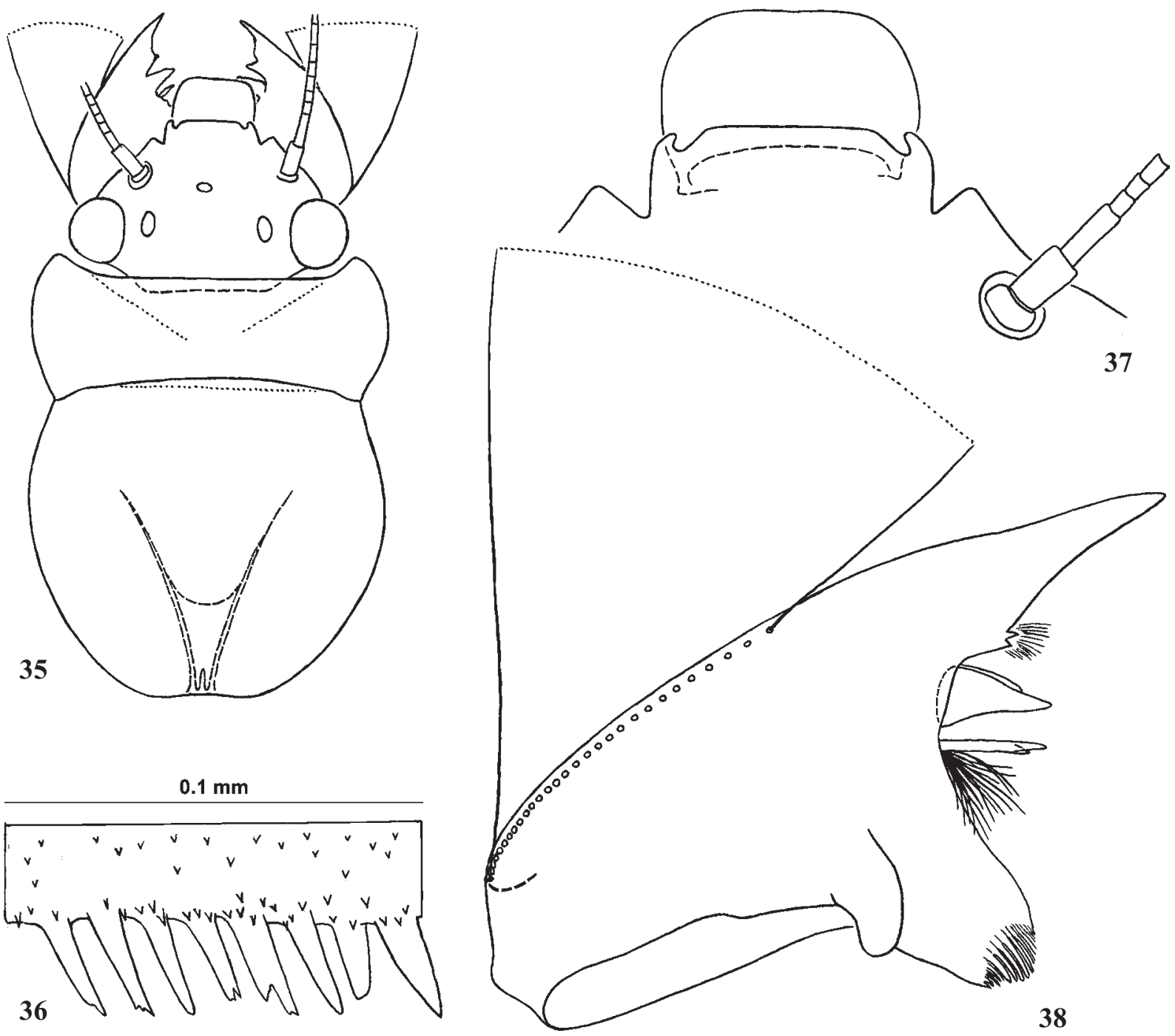
clypeus and part of frons; 38 - left mandible (most of long setae not shown, area occupied by them shown by dotted line).

Рис. 35-38. Tricorythus tinctus, личинка: 35 - голова, пронотум и мезонотум; 36 - задний край VII тергита брюшка; 37 верхняя губа, клипеус и часть лба; 38 - левая мандибула (большая часть длинных щетинок не показана, занимаемая ими область показана точечной линией). 


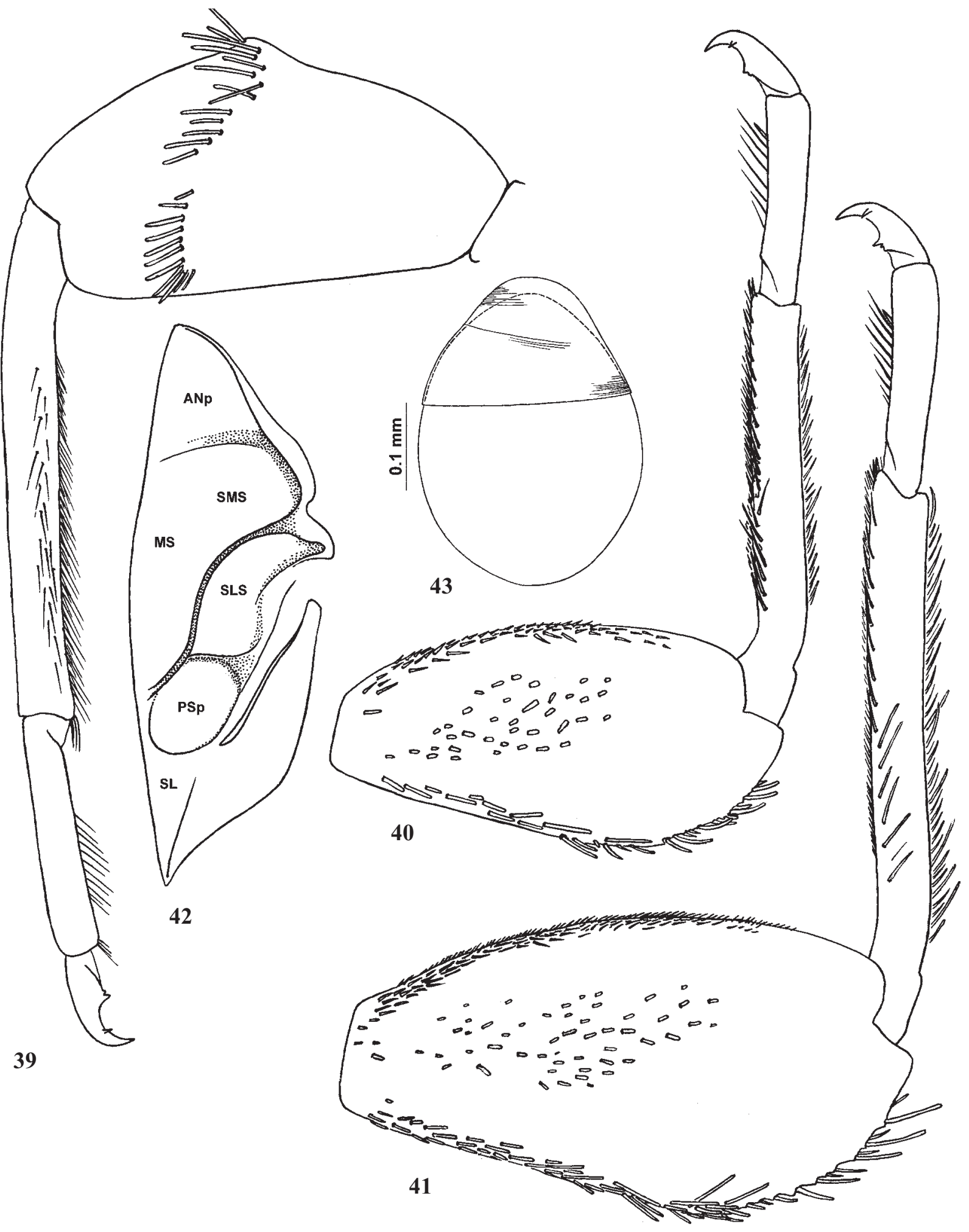

Figs 39-43. Tricorythus tinctus: $39-41$ — right fore, middle and hind legs of last instar male larva, dorsal (anterior) view; 42 - right half of subimaginal exuviae of male mesonotum (brown cuticular pigmentation shown by dots; ANp - anteronotal protuberance; MS medioscutum; SMS — submedioscutum; SLS — sublateroscutum; PSp — posterior scutal protuberance; SL — scutellum); 43 - egg.

Pис. 39-43. Tricorythus tinctus: 39-41 — правые передняя, средняя и задняя ноги личинки самца последнего возраста, дорсально (спереди); 42 - правая половина субимагинального экзувия мезонотума самца (пунктировкой показана бурая кутикулярная пигментация; ANp — передненотальный бугор; MS - медиоскутум; SMS - субмедиоскутум; SLS - сублатероскутум; PSp заднескутальный бугор; SL — скутеллум); 43 - яйцо. 
Femora of moderate width; stout setae on femora (which form rows characteristic for Pantricorythi) are moderately long and blunt, form regular rows: on fore femur transverse row of stout setae is regular, not continuous on outer margin; on middle and hind femora row of stout setae along outer margin is nearly regular (Figs 39-41). Fore tarsus in male larva is not widened, the same as in female larva.

Denticles on hind margins of abdominal terga are long, stout, most of them pointed, some blunt or terminating by several points (Fig. 36). Vestiges of tergalii VII are absent

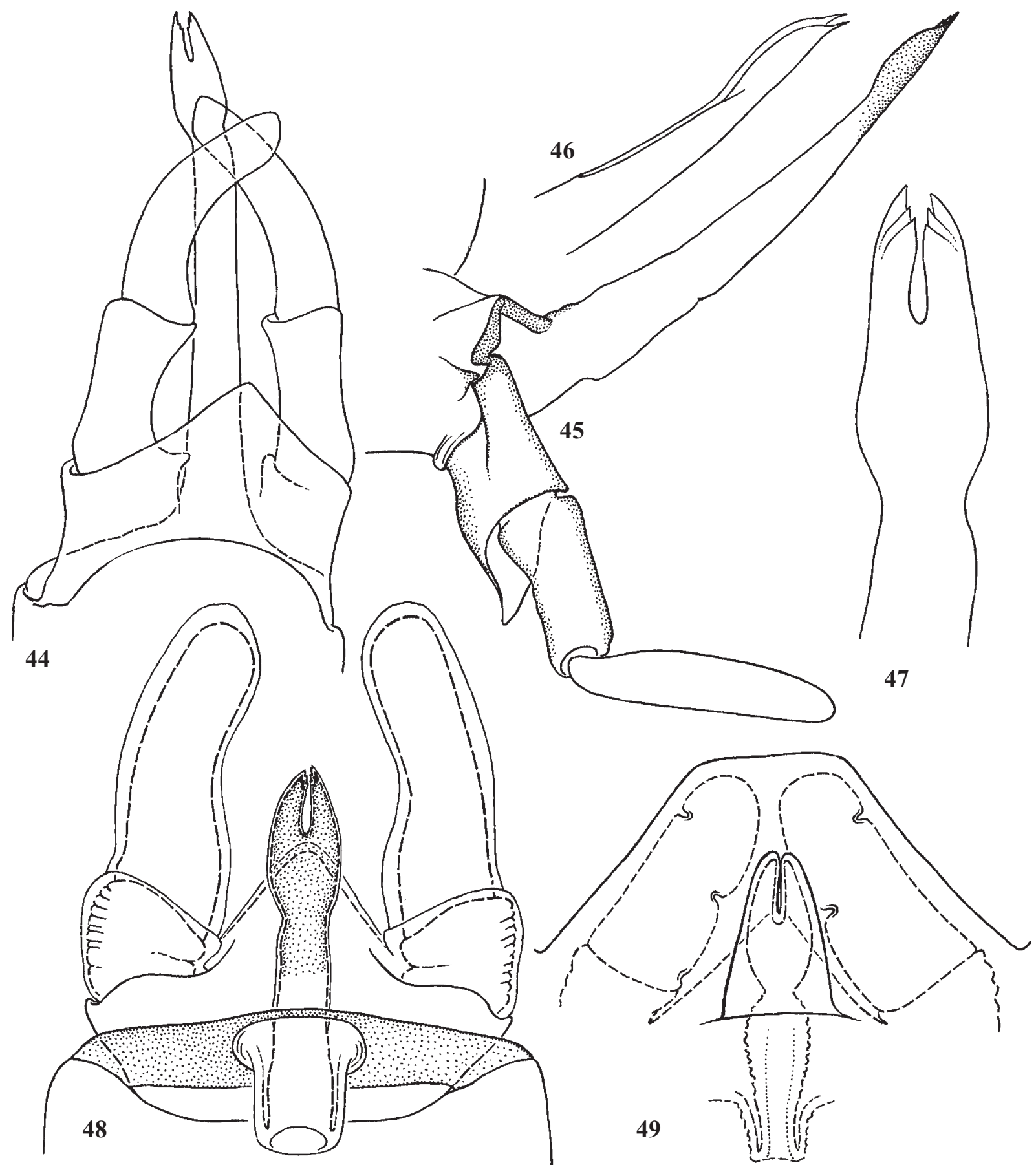

Figs 44-49. Tricorythus tinctus, male genitals: 44 - genitals of imago, ventral view; 45 - the same, lateral view; 46 - apex of penis, lateraldorsal view; 47 - the same, ventral view; 48 - genitals of subimago, dorsal view (imaginal cuticle shown by interrupted lines); 49 - genital buds of larva before molt to subimago (subimaginal cuticle shown by interrupted line).

Рис. 44-49. Tricorythus tinctus, гениталии самца: 44 - гениталии имаго, вентрально; 45 — то же, латерально; 46 - вершина пениса, латерально-дорсально; 47 — то же, вентрально; 48 — гениталии субимаго, дорсально (имагинальная кутикула показана прерывистой линией); 49 - зачатки гениталий личинки перед линькой на субимаго (субимагинальная кутикула показана прерывистой линией). 
(unlike larvula - Fig. 31). Protopenis is not long, far from reaching hind margin of sternum IX, with narrow median incision (Fig. 49) (see below).

Young larvula lacks species-specific larval features listed above: frons and clypeus have no paired projections; mandibular incisors are not projected (Fig. 31).

Subimago, male. CUTICULAR COLORATION AND TEXTURE: Cuticle of thorax is nearly colorless, with some sclerites light brown. Mesonotum is light, with antelateroparapsidal and lateroparapsidal sutures darker (Fig. 42). Microtrichiae densely cover all areas of mesonotum except for posterior scutal protuberances; cuticle of posterior scutal protuberances lacks microtrichiae, smooth (see Table). On fore leg cuticle of femur in most part is colorless, with four contrasting brown stripes along outer and inner margins, cuticle of tibia and tarsus is colorless. On middle and hinge legs cuticle is entirely colorless. Cuticle of abdomen and caudalii is entirely colorless.

Hypodermal COLORATION: As in imago.

Imago, male. HYPODERMAL AND CUTICULAR COLORATION: Head has dark gray hypodermal maculation. Prothorax has dark gray and purple hypodermal maculation. Pterothorax is light ocher, with pale grayish hypodermal maculation. Each femur has gray hypodermal maculation, with blanks at base, at apex and at middle. Each tibia is colorless, with pale gray hypodermal stripe on outer side. Tarsi are colorless. Wings are light. Abdominal terga have light gray and purple maculation; side areas corresponding to larval tergalial cavities (see characteristics of Tricorygnatha) are colorless; sterna are colorless, only lateral sides of posteriormost sterna have gray hypodermal maculation. Styliger, gonostyli, penis and caudalii are also colorless.

SHAPE: Eyes are small. Genitals as in Figs 44-47: Sternum IX lacks lines bordering areas of attachment of sternostyligeral muscles: these muscles are attached all over width of sternum. Styliger has large median projection. Penis has unpaired portion long, nearly straight, slightly arched dorsally; paired distal part is short, each its lobe bears 3 sclerotized denticles on inner side.

Development of male genitals. In imago unpaired proximal stem of penis is very long (Figs 44-45). In subimago unpaired stem is much shorter because its proximal part is inverted and retracted telescopically (Fig. 48). In larva of last instar, subimaginal penis develops in this retracted condition; larval protopenis is relatively short (Fig. 49), shorter than in some other Tricorygnatha (compare with Fig. 20). In male imago and subimago styliger medially has a large triangular projection (Figs 44, 48); this projection corresponds to larval triangular portion of sternum IX, which locates between areas corresponding to gonostyli (Fig. 49).

Egg (extracted from mature larva). Dark brown, with contrasting silver polar cap. Polar cap is very large, covers about $1 / 3$ of egg (Fig. 43). Surface lacks visible reticulation.

DIMENSION. Fore wing length (and approximate body length) of male $6 \mathrm{~mm}$.

EMERGENCE. Larvae were collected in upper part of river Nile, which has fast current and rocky bottom. Each evening, at the beginning of darkness, myriads male subimagoes were attracted to lamps on the bank and molted to imagoes during the same night. Female adults were not attracted to light; I was able to collect 400 male subimagoes and imagoes and no one female adult. Certain rocks of the river bank and certain lives of plants growing close to the water, were completely covered by male larval exuviae, sitting close one to another, so that their density was 2-3 $\mathrm{spm} . / \mathrm{cm}^{2}$, at some places up to $7 \mathrm{spm} . / \mathrm{cm}^{2}$.

\section{Tricorythus sp. I}

MATERIAL. UGANDA, Kanungu district, river Ishasha, 14.VII.2007, coll. N. Kluge: 2 female larvae, 2 female adults (presumably attributed to the same species).

Larva. Similar to T. tinctus: head has paired projections on frons and clypeus; each mandible has incisor projected into a long pointed tusk, straight in dorsal view and slightly curved dorsally. Pronotum is wide, with antero-lateral angles strongly projected forward.

Differs from $T$. tinctus by the following characters: Mandibular tusks are longer. Hind tibiae are shorter and thicker, with longer setae.

Female, adult. Body and legs are light, certain areas have light brown cuticular pigmentation and/or gray hypodermal pigmentation. Each femur has four brown cuticular stripes along outer and inner margins and gray longitudinal stripes on anterior and posterior surfaces. Femora are not wide. Wings are light. Wing length $7 \mathrm{~mm}$.

The fact that females of this species have no subimaginal/ imaginal molt, is proven by the fact that claws of female adults do not contain imaginal claws, while their wings are covered by subimaginal microtrichiae.

\section{Tricorythus sp. $\mathbf{N}$}

Tricorythus tinctus: Kluge, 2004: Fig.98E-G (non Kimmins, 1956) MATERIAL. SUDAN, White Nile, river Sabat near Saide, 28.XII.1963, coll. A. Monakov: 30 larvae.

Larva. Similar to T. tinctus: head has paired projections on frons and clypeus; each mandible has incisor projected into a long pointed tusk, straight in dorsal view and slightly curved dorsally. Eyes of male are as small as in female. Pronotum is wide, with antero-lateral angles strongly projected forward, anterior margin between them in both sexes straight.

Differs from $T$. tinctus by the following characters: Tibiae of all legs are much longer. Protoptera of immature larva (at least at the last instar) have hypoderm with very contrasting coloration: basal-costal part of protopteron is entirely dark blackish-brown, so that veins are indistinguishable; distal part of protopteron has hypoderm of wing membrane colorless, longitudinal veins are bordered by dark. This coloration is so intensive, that completely retains on specimens which after 40 -years preservation in alcohol lost other pigmentation.

\section{Tricorythus sp. S}

MATERIAL. MALI, upper Senegal river, barrage de Manuntali, 7-9.XI.1990, coll. W. Tobias: $3 \mathrm{O}^{7}$ imagoes.

Imago, male. Genitals are similar to that of T. tinctus: styliger with large median projection; penis has unpaired portion long; paired distal portion of penis is short, each its lobe bears 3 sclerotized denticles on inner side. Eyes are small.

Differs from $T$. tinctus by the following character: unpaired stem of penis is more strongly arched dorsally.

\section{Tricorythus discolor (Burmeister, 1839 [Oxycypha])} Figs 50-51

Oxycypha discolor Burmeister, 1839 (female imago).

Caenis discolor: Pictet, 1845-1845.

Cloeon discolor: Walker, 1853

Tricorythus discolor: Eaton, 1883-1888 (female imago).

Tricorythus discolor: Ulmer, 1921 (female imago).

Tricorythus discolor: Barnard, 1932 (male imago, subimago, larva, egg).

MATERIAL. SOUTH AFRICA, Tugela river system, river Mooi, Glenfern Bridge, 15.III.1995, coll. C. Dickens: 11 larvae (Albany Museum No. MOI 72AM). 


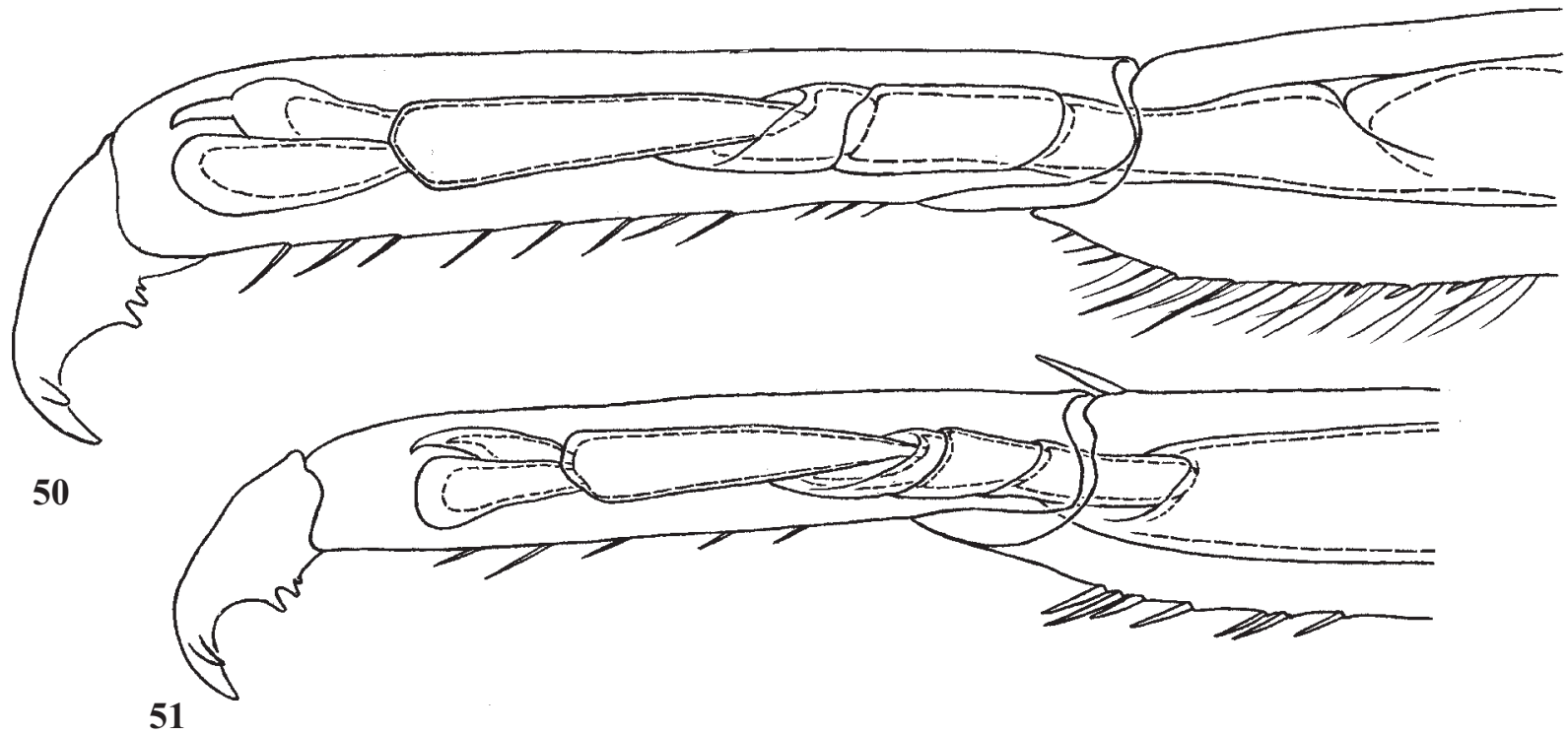

Figs 50-51. Tricorythus discolor, tarsi of male larva before molt to subimago: 50 — fore leg; 51 - middle leg (subimaginal cuticle shown by integral line; imaginal cuticle shown by interrupted line) [from Kluge, 2004: Fig. 98A, B, corrected].

Рис. 50-51. Tricorythus discolor, лапки личинки самца перед линькой на субимаго: 50 - передняя нога; 51 - средняя нога (субимагинальная кутикула показана сплошной линией; имагинальная кутикула показана прерывистой линией) [по Kluge, 2004: Fig. 98А, В, исправлено].

Larva, imago and egg: described by Barnard [1932]. Larval maxilla, subimaginal mesopleuron and male larval progenitals with developing subimaginal and imaginal genitals are figured by Kluge [2004: Figs 97A-D, 98C].

Male subimago and female adult. CUTICULAR TEXTURE: Microtrichiae densely cover all areas of mesonotum except for posterior scutal protuberances; posterior scutal protuberances at most part lack microtrichiae, smooth, with a few small setae (as small as microtrichiae); only sides of posterior scutal protuberances bear microtrichiae and net-like relief (see Table).

The fact that females have no subimaginal/imaginal molt, is proven by the fact that claws of adult, which can be seen inside tarsus of female larva before larval/subimaginal molt, do not contain imaginal claws; unlike them, claws of male subimago contain imaginal claws before larval/subimaginal molt (Figs 50-51)

\section{Tricorythus exophthalmus Kluge, sp.n.} Figs $52-70,88$

MATERIAL. Holotype: L-SO $0^{7}$ specimen [XXI](2A)\}: UGANDA, Kanungu district, river Munyaga near camping of Bwind National Park, 1.VIII.2007, coll. N. Kluge. Paratypes: the same locality, 21-25.VII.2007: many larvae; river Ishasha near Butogota, 14.VII.2007, coll. N. Kluge: 8 larvae.

Larva. Cuticular COloration and teXture: Cuticle is light-brownish; pronotum has paired branched blanks (Fig. 55). Certain areas of cuticle bear numerous small dark protuberances; these protuberances locate on surface of cuticle and consist of dark brown rough bodies surrounded or covered by lighter cuticle (Figs 55-57, 64-65); protuberances have irregular shape, either separated one from another, or contiguous, forming ornament (Fig. 65); at some areas protuberances surround sensory craters, which are round and colorless, so that cuticle looks as covered by dark rings (Fig. 57). The dark protuberances are present on the following areas: On the head protuberances are present on most part of head capsule, compound eyes, at proximal part of labrum and proximal part of outer surface of mandibles. On the thorax: pronotum (Fig. 55), mesonotum and protoptera bear contrasting dark protuberances; certain areas of pleura and sterna bear lighter protuberances. Dorsal surfaces of femora have colorless craters, surrounded by irregular ring-like dark protuberances: on fore femur these protuberances are present in distal half, distad of the transverse row of setae (Fig. 60); on middle and hind femora they are present at most part, except for longitudinal stripe in middle (Figs 62-63). Dorsal surfaces of all tibiae and tarsi have protuberances. On the abdominal terga protuberances are present on most part of surface, except for tergalial cavities (see diagnosis of Tricorygnatha), which completely lack these protuberances. On the abdominal sterna protuberances are present on most part of surface, except for median areas corresponding to nerve ganglia. Caudalii lack protuberances.

Hypodermal coloration: Living male larva has upper portion of eyes dull orange or brown, lower portion black (Fig. 88). Head and thorax dorsally have dark maculae, thorax ventrally light. Fore femur (dorsally and ventrally): proximal half is light, often with diffusive dark macula near base; distal half has two wide longitudinal dark stripes separated by a narrower longitudinal blank. Middle and hind femur dorsally with two wide longitudinal dark stripes separated by narrower longitudinal blank, ventrally lighter. Each tibia is dark in proximal part, light in distal part. Hypoderm of protoptera of all instars is very dark (Fig. 88), veins either of the same color and invisible, or somewhat lighter. Abdominal terga are dark, sterna of fore segments are lighter, sterna of hind segments are dark. Tergalii have dorsal lamellate lobe gray with margins colorless, ventral bifurcate lobe gray. Caudalii are proximally dark, distally light.

ShaPe AND SETATION: Frons and clypeus lack projections (Fig. 52). Eyes of male are large, prominent, much larger than in female (Figs 52-54, 88). Mandibles have incisors not 
elongated, curved (as in Fig. 4); left prostheca is asymmetrically widened apically, with many bristle-like processes at base (Fig. 58); right prostheca has shape usual for Tricorygnatha (Fig. 59). Number of setae in transverse row on ventral side of maxilla is 10-13 (in last larval of instar). Maxillary palps are long (unlike Sparsorythus)
Pronotum is wide; anterolateral angles are strongly projected forward; anterior margin between them in male is strongly convex, in female straight; mesonotum has fore protoptera short (Figs 52-54, 88). Femora are wide; stout setae on femora (which form rows characteristic for Pantricorythi) are short, apically widened and blunt, form regular rows: on fore femur
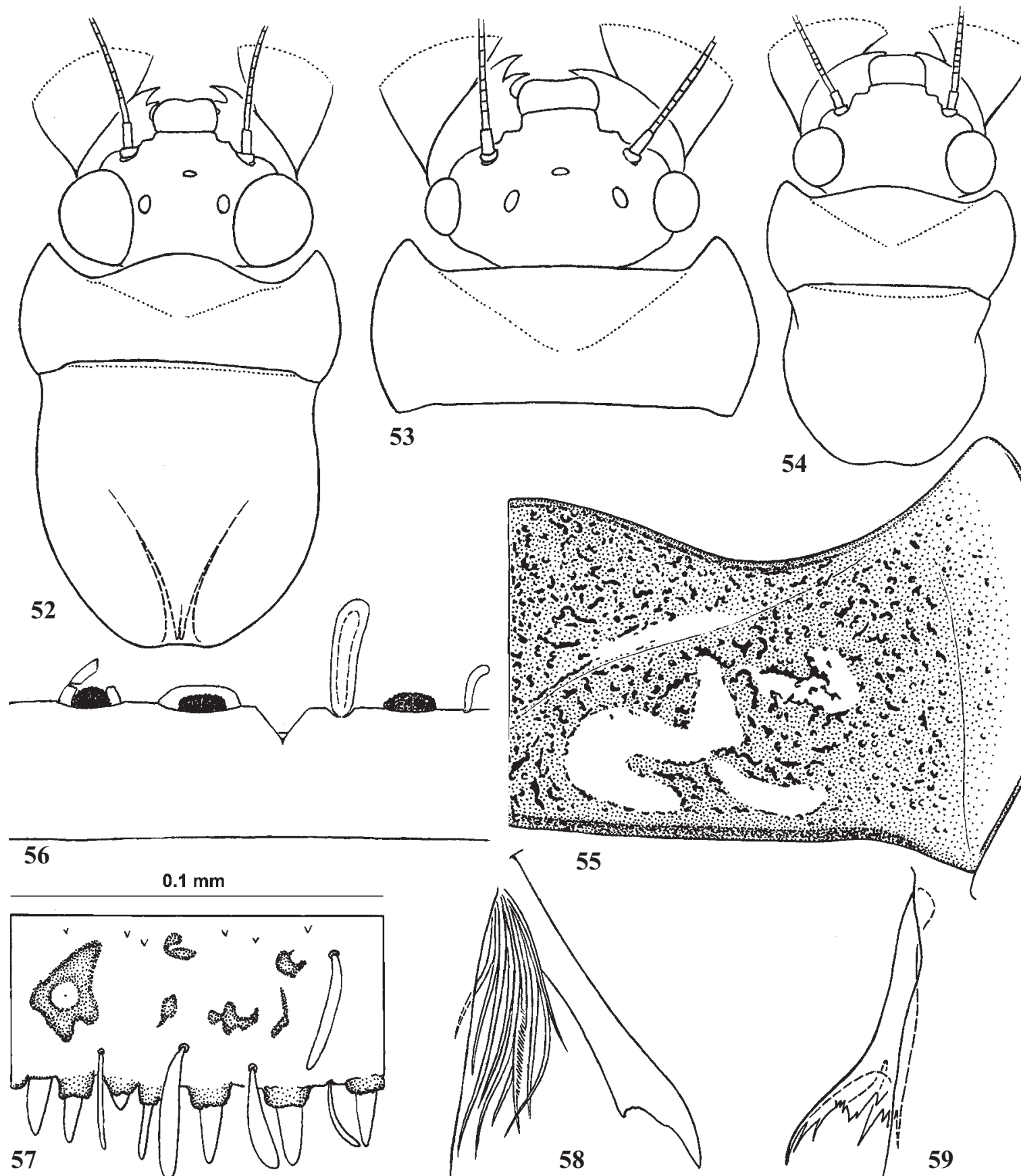

54
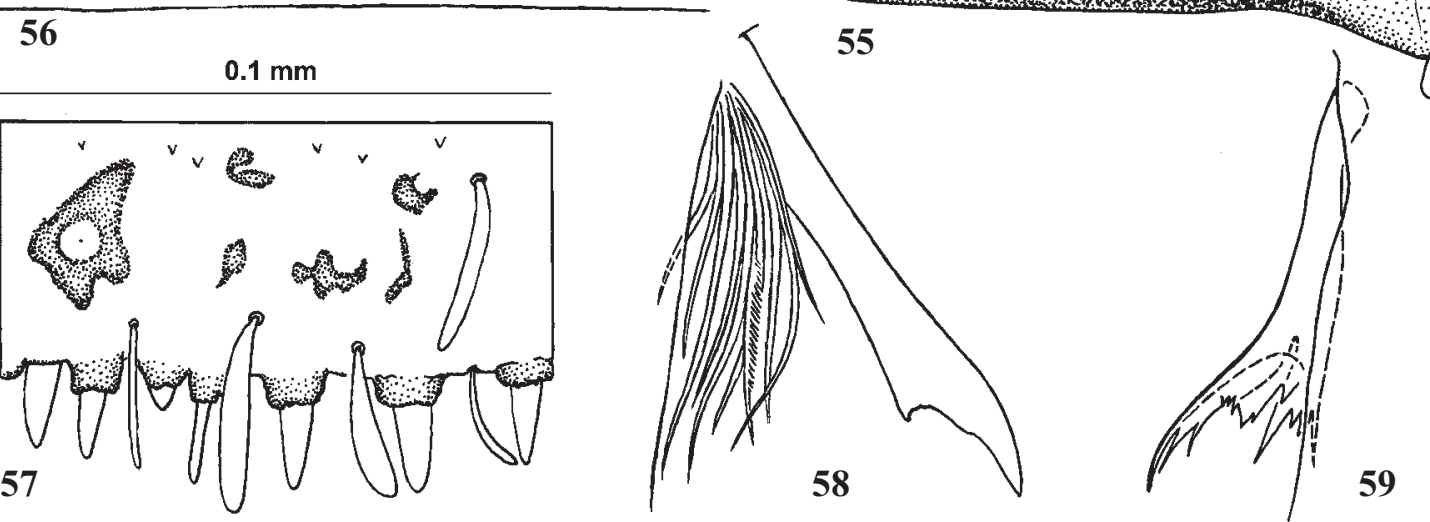

Figs 52-59. Tricorythus exophthalmus sp.n., larva: 52 — head, pronotum and mesonotum of last instar male larva; 53 — the same, female larva; 54 - the same, younger male larva; 55 - exuviae of right half of pronotum of last instar male larva (cuticular pigmentation shown by dots, brown protuberances shown by black spots); 56 — cross section through cuticle of pronotum; 57 — hind margin of abdominal tergum VII (cuticular pigmented protuberances shown by dots); 58-59 - left and right prosthecae.

Рис. 52-59. Tricorythus exophthalmus sp.n., личинка: 52 — голова, пронотум и мезонотум личинки самца последнего возраста; 53 - то же, личинка самки; 54 - то же, более молодая личинка самца; 55 - экзувий правой половины пронотума личинки самца последнего возраста (кутикулярная пигментация показана пунктировкой, бурые бугорки показаны чёрными пятнами); 56 поперечный срез кутикулы пронотума; 57 — задний край VII тергита брюшка (кутикулярные пигментированные бугорки показаны пунктировкой); 58-59 - левая и правая простеки. 


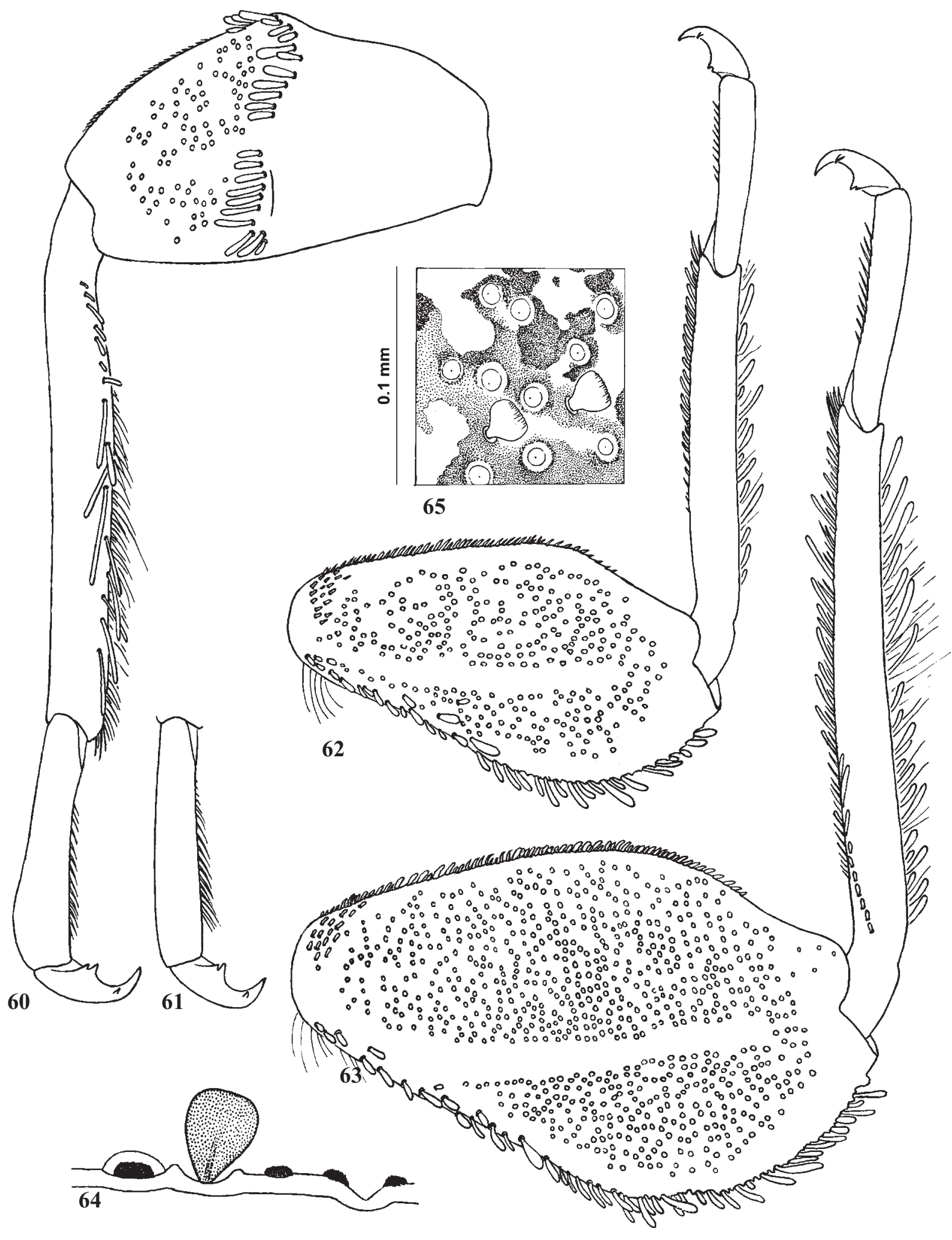

Figs 60-64. Tricorythus exophthalmus sp.n., larva: 60, 62-63 — right fore, middle and hind legs of last instar male larva, dorsal (anterior) view (areas covered by dark protuberances shown by small rings); 61 - fore tarsus of last instar female larva; 64 - cross section of cuticle of femur; 65 - fragment of cuticle of fore femur (pigmented protuberances shown by dots).

Рис. 60-64. Tricorythus exophthalmus sp.n., личинка: 60, 62-63 - правые передняя, средняя и задняя ноги личинки самца последнего возраста, дорсально (спереди) (области, покрытые тёмными бугорками, показаны кружочками); 61 — передняя лапка личинки самки последнего возраста; 64 - поперечный срез кутикулы бедра; 65 - участок кутикулы переднего бедра (пигментированные бугорки показаны пунктировкой). 
transverse row of stout setae is regular, not continuous on outer margin; on middle and hind femora row of stout setae along outer margin is regular (Figs 60-63). In mature male larva fore tarsus is swollen apically (Fig. 60), in female larva it is normal (Fig. 61) (unlike other species examined).

On abdominal terga, tergalial cavities (which in contrast to other surface lack dark protuberances - see above) are bordered by dense band-like setae. Denticles on hind margins of abdominal terga are not large, variable, irregular, some have darkened bases (Fig. 57). Vestiges of tergalii VII are absent. Protopenis is not long, far not reaching hind margin of sternum IX, with narrow median incision (Fig. 69) (unlike wide incision in imago)

Subimago, male. CUTICULAR COLORATION AND TEXTURE: Cuticle of pronotum is light brownish with blanks of compos- ite branched shape, densely covered with microtrichiae except for blanks. Mesonotum, including posterior scutal protuberances, is entirely covered by dense microtrichiae (see Table). Antelateroparapsidal suture and anterolateral scutal costa are brown; other parts of mesonotum and basal sclerite of wing are light brownish. Cuticle of thoracic sterna is colorless. Cuticle of legs is partly colorless, with intensive contrasting longitudinal stripes: each femur has four stripes along outer and inner margins; each tibia has brown basal part and stripe along outer margin; each tarsus is at most part brown. Cuticle of abdominal terga and sterna is light brown, with small, contrasting, paired blanks. Gonostyli have dark band at joining of first and second segment. Cuticle of caudalii is colorless.

Hypodermal coloration: As in imago.

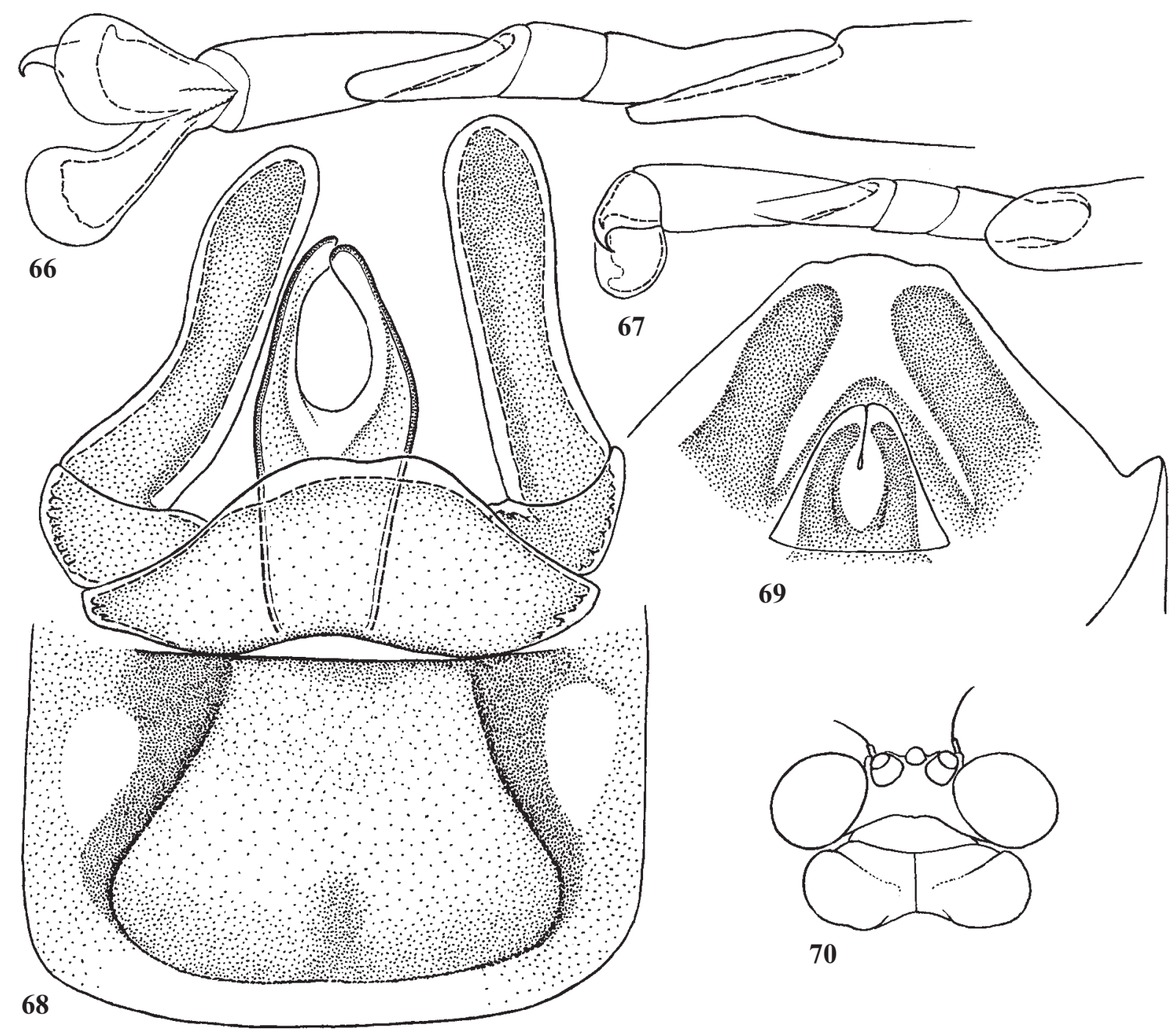

Figs 66-70. Tricorythus exophthalmus sp.n.: 66-67 - tarsus of fore and middle legs of male subimago (imaginal claws shown by interrupted lines); 68 - genitals of male subimago (gray hypodermal pigmentation shown by dots); 69 - genital buds of last instar male larva, dorsal view (larval cuticle shown by integral lines, tissues by dots); 70 - head and pronotum of male subimago.

Рис. 66-70. Tricorythus exophthalmus sp.n.: 66-67 - лапки передней и средней ноги самца субимаго (имагинальные коготки показаны прерывистыми линиями); 68 - гениталии самца субимаго (пунктировкой показана серая гиподермальная пигментация); 69 - зачатки гениталий личинки последнего возраста, дорсально (личиночная кутикула показана сплошной линией, пунктировкой показаны ткани); 70 — голова и пронотум самца субимаго. 
Imago, male. HYPODERMAL AND CUTICULAR COLORATION: Head and prothorax have intensive dark gray hypodermal maculation. Mesonotum has cuticle light brown; longitudinal gray hypodermal stripes are visible through cuticle. Ventral side of pterothorax has characteristic coloration: pair of episterna have cuticle light brown; basisternum between them has cuticle colorless, hypoderm light gray; furcasternum has cuticle colorless, its paired protuberances are whitish, its median impression with dark gray hypodermal coloration. Legs have intensive dark gray hypodermal pigmentation: fore femur distally is gray with diffusive light longitudinal stripes, proximally light with diffusive gray macula near base; middle and hind femora are entirely gray with diffusive light longitudinal stripes. Wings are dark gray. Abdominal terga and sterna look nearly unicolor thanks to intensive dark gray hypodermal pigmentation. Styliger, gonostyli and penis also have gray hypodermal pigmentation. Caudalii are gray.

SHAPE: Eyes are large, located laterally, widely separated (Fig. 70). Genitals as in Fig. 68: Sternum IX has well expressed dark lines, which border areas of attachment of sterno-styligeral muscles; these lines are lyre-shaped, converging toward styliger. Penis is wide, with paired lobes widely separated basally and converging apically.

Development of male genitals. Larval protopenis has narrow median incision, like that of other species; unlike it, adult penis has median incision unusually wide (Figs 68-69).

Adult, female. Unknown

Egg. Unknown.

DIMENSION. Wing length (and approximate body length) of male $7 \mathrm{~mm}$.

COMPARISON. Larva of the new species differs from other Tricorygnatha by peculiar relief on dorsal side of head, thorax, abdomen and femora. Male imago and subimago differs from all other Tricorygnatha by arched and widely diverging paired lobes of penis. Subimago differs from other examined species of Tricorygnatha by dense microtrichiae on posterior scutal protuberances. Mature larva, besides sexual dimorphism in shape of caudalii (characteristic for Tricorygnatha), has sexual dimorphism in shape of eyes, pronotum and fore tarsus.
EMERGENCE. Larvae were collected only in that part of river Munyaga, where it forms the boundary of Bwindi National Park and runs in deep shad of the forest; they were not found lower, where the river runs on the opened place. Probably, larvae of $T$. exophthalmus need shad and cool water. At 21-25.VII, I was able to collect many larvae of the last instar, but no one of them was ready to molt to subimago. The single male subimago was reared by me later, from the larva which I took with me to another place. Probably, $T$. exophthalmus has seasonal development, in spite of equatorial climate.

\section{Tricorythus sp. $\mathrm{R}$}

MATERIAL. CAMEROON, Kumba district, Menge river, 2.V.1969, coll. R.H.L. Disney: 9 larvae. RWANDA, pref. Ruhengeri, rte de Rushoshi, river Basel, 25.XII.1987, coll. P. Landolt \& D. Studemann: 13 larvae.

Larva. Similar to T. exophthalmus, but without pigmented protuberances on head, notum and legs.

Subimago, imago, eggs. Unknown.

\section{Tricorythus (Sparsorythus) celebensis Kluge, sp.n. Figs 71-85, 89}

Sparsorythus sp. 5: Sroka \& Soldan, 2008.

MATERIAL. Holotype: L-S-I ${ }^{7}$ \{specimen [XIV](3)B $\}$ : INDONESIA, SULAWESI, tributary of river Mamasa $5 \mathrm{~km}$ W Mamasa, 25.VIII.2009, coll. N. Kluge \& L. Sheyko. Paratypes: the same locality, 15-27.VIII.2009: 5 L-S-IO7, 8 L-SO’, 8 L-A 9 , 140 L.

Larva. Cuticular COlORATion: Whole cuticle is lightbrownish, nearly unicolor, without maculation. Band-like setae (see below) are brown, darker than cuticle.

Hypodermal coloration: Head, thorax, legs and abdomen are dorsally blackish, sometimes with diffusive lighter areas; ventrally lighter. Protoptera in all instars are dark (Fig. 89): hypoderm of wing membrane is uniformly dark brown, veins lighter, poorly visible. Tergalii are uniformly gray. Caudalii are either uniformly light, or with alternating dark and light segments in proximal part.

SHAPE AND SETATION: Body is covered by brown band-like setae (Fig. 76); being darker than cuticle, these setae are well-

Table. Cuticular texture of mesonotum of male subimago and female adult Таблица. Кутикулярная текстура мезонотума самца имаго и взрослой самки

\begin{tabular}{|c|c|c|c|c|c|c|c|c|}
\hline & $\mathrm{ANp}$ & MS & SMS & $\begin{array}{l}\text { SLS } \\
\text { (a) }\end{array}$ & $\begin{array}{l}\text { SLS } \\
(\mathrm{p})\end{array}$ & LS & PSp & $\mathrm{SL}$ \\
\hline Tricorythus varicauda $\mathrm{O}^{7}$ & MM & MM & MM & MM & MM & $\mathrm{M}$ & $\mathrm{R}+\mathrm{M}$ & $\overline{\mathrm{MM}}$ \\
\hline Tricorythus varicauda 9 & MM & MM & MM & MM & MM & M & $\mathrm{R}$ & MM \\
\hline Tricorythus tinctus $0^{7}$ & MM & MM & MM & MM & MM & M & - & MM \\
\hline Tricorythus discolor $0^{7}$ & MM & MM & MM & MM & MM & $\mathrm{M}$ & - & $\overline{\mathrm{MM}}$ \\
\hline Tricorythus discolor ${ }^{+}$ & MM & $\mathrm{MM}$ & MM & MM & MM & $\bar{M}$ & - & $\overline{\mathrm{MM}}$ \\
\hline Tricorythus exophthalmus $\mathrm{O}^{7}$ & MM & MM & MM & MM & MM & $\mathrm{M}$ & MM & $\mathrm{MM}$ \\
\hline Tricorythus celebensis $0^{7}$ & MM & $\mathrm{MM}$ & MM & MM & - & $\mathrm{M}$ & $\mathrm{R}+\mathrm{M}$ & $\overline{\mathrm{MM}}$ \\
\hline 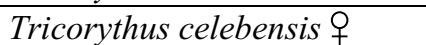 & MM & MM & MM & MM & MM & $\mathrm{M}$ & $\mathrm{R}+\mathrm{M}$ & $\mathrm{MM}$ \\
\hline
\end{tabular}

Table legend: ANp — anteronotal protuberance; MS — medioscutum; SMS — submedioscutum; SLS(a) — anterior half of sublateroscutum; SLS (p) - posterior half of sublateroscutum; LS - lateroscutum; PSp — posterior scutal protuberance; SL - scutellum; MM — densely covered by microtrichiae; $\mathrm{M}$ - partly covered by microtrichiae; $\mathrm{R}$ — prominent reticulation (see Fig. 42).

Легенда: ANp — передненотальный бугор; MS — медиоскутум; SMS — субмедиоскутум; SLS(a) — передняя половина сублатероскутума; SLS(p) — задняя половина сублатероскутума; LS — латероскутум; PSp — заднескутальный бугор; SL — скутеллум; MM - густо покрыто микротрихиями; M - частично покрыто микротрихиями; R - выступающий сетчатый рельеф (см. рис. 42). 


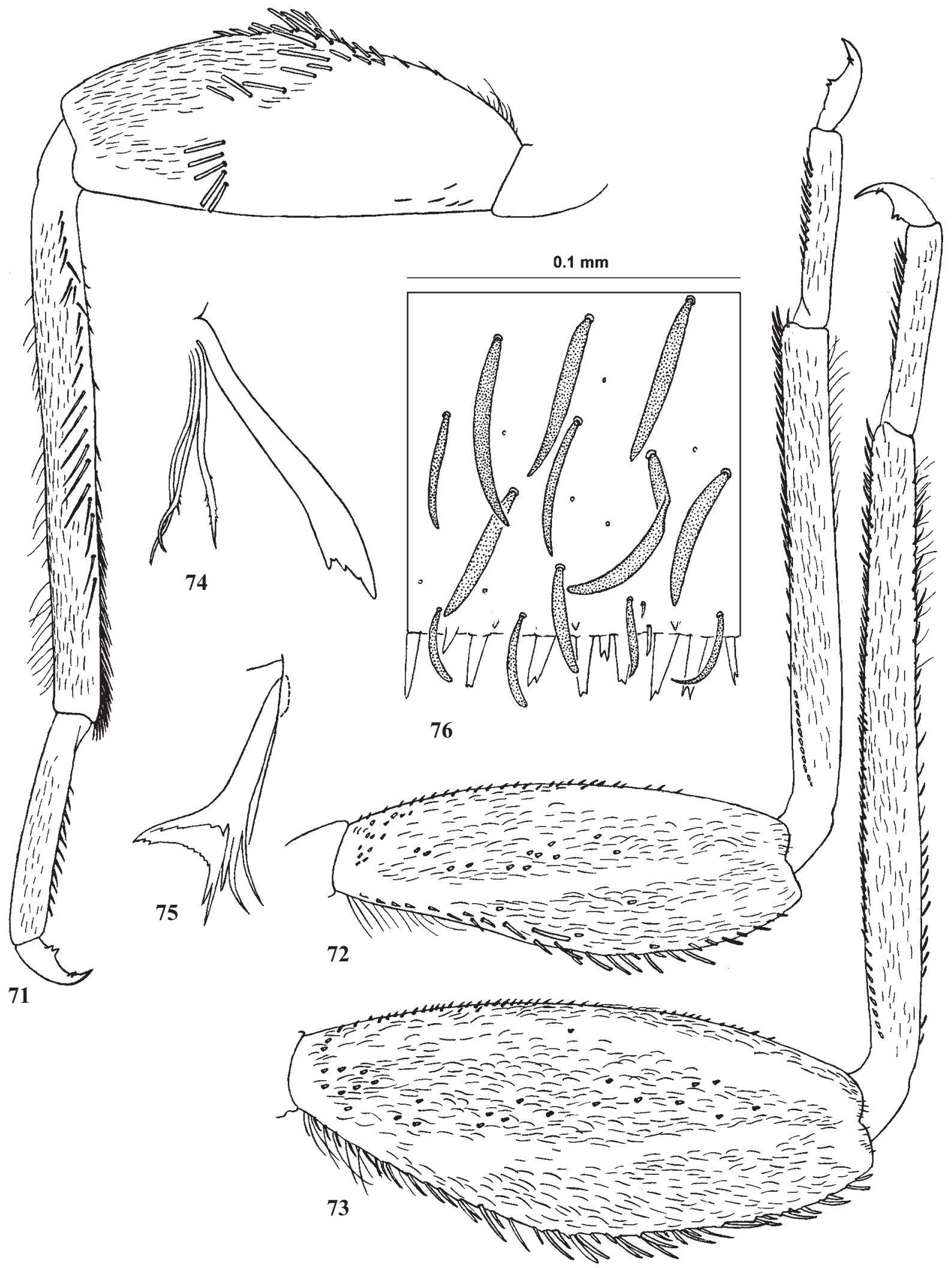

Figs 71-76. Tricorythus (Sparsorythus) celebensis sp.n., larva: 71-73 — right fore, middle and hind legs of last instar male larva, dorsal (anterior) view; 74-75 - left and right prosthecae; 76 - hind margin of abdominal tergum VII.

Рис. 71-76. Tricorythus (Sparsorythus) celebensis sp.n., личинка: 71-73 — правые передняя, средняя и задняя ноги личинки самца последнего возраста, дорсально (спереди); $74-75$ - левая и правая простеки; 76 - задний край VII тергита брюшка. 
visible on empty exuviae, but are less visible on intact specimens, which have dark hypodermal coloration. These bandlike setae locate on certain areas of head, on pedicels of antennae, on lateral areas of mandibles, on most part of labrum, on certain areas of pronotum, mesonotum, thoracic sterna and pleura, on all sides of legs, except for proximal half of fore side of fore femora (Fig. 71) and on all abdominal terga and sterna, except for tergalial cavities of abdominal terga; they are absent on caudalii.

Frons and clypeus lack projections (Fig. 77). Labrum is relatively wide (Fig. 77). Mandibles have incisors not elongated, curved (as in Fig. 4); left prostheca is asymmetrically widened apically, with 3 bristle-like processes at base (Fig. 74); right prostheca has shape usual for Tricorygnatha (Fig. 75). Number of setae in transverse row on ventral side of maxilla is $11-15$ (in last larval instar). Maxillary palps are absent.

Pronotum of moderate width; anterolateral angles are only slightly projected forward; anterior margin between them in both sexes is straight; mesonotum is not shortened (Figs 77, 89). Legs as in Figs 71-73: Femora are not wide. Stout setae on femora (which form rows characteristic for Pantricorythi) are elongate, apically blunt or pointed, situated irregularly: on fore femur transverse row of stout setae is irregular, not continuous on outer margin; on middle and hind femora row of stout setae along outer margin is irregular. Fore tarsus in male larva is not widened, the same as in female larva.

Denticles on hind margins of abdominal terga are elongate, either pointed, or blunt, or terminating by several points (Fig. 76). Vestiges of tergalii VII are absent. Protopenis is very short and separated into two halves nearly up to base (Fig. 85) (see below).

Subimago, male. Cuticular coloration and texture: Cuticle of mesonotum is light brown with blanks of composite branched shape; densely covered with microtrichiae except for blanks. Cuticle of pterothorax has sclerites light brown and membranes colorless. On mesonotum, antelater-

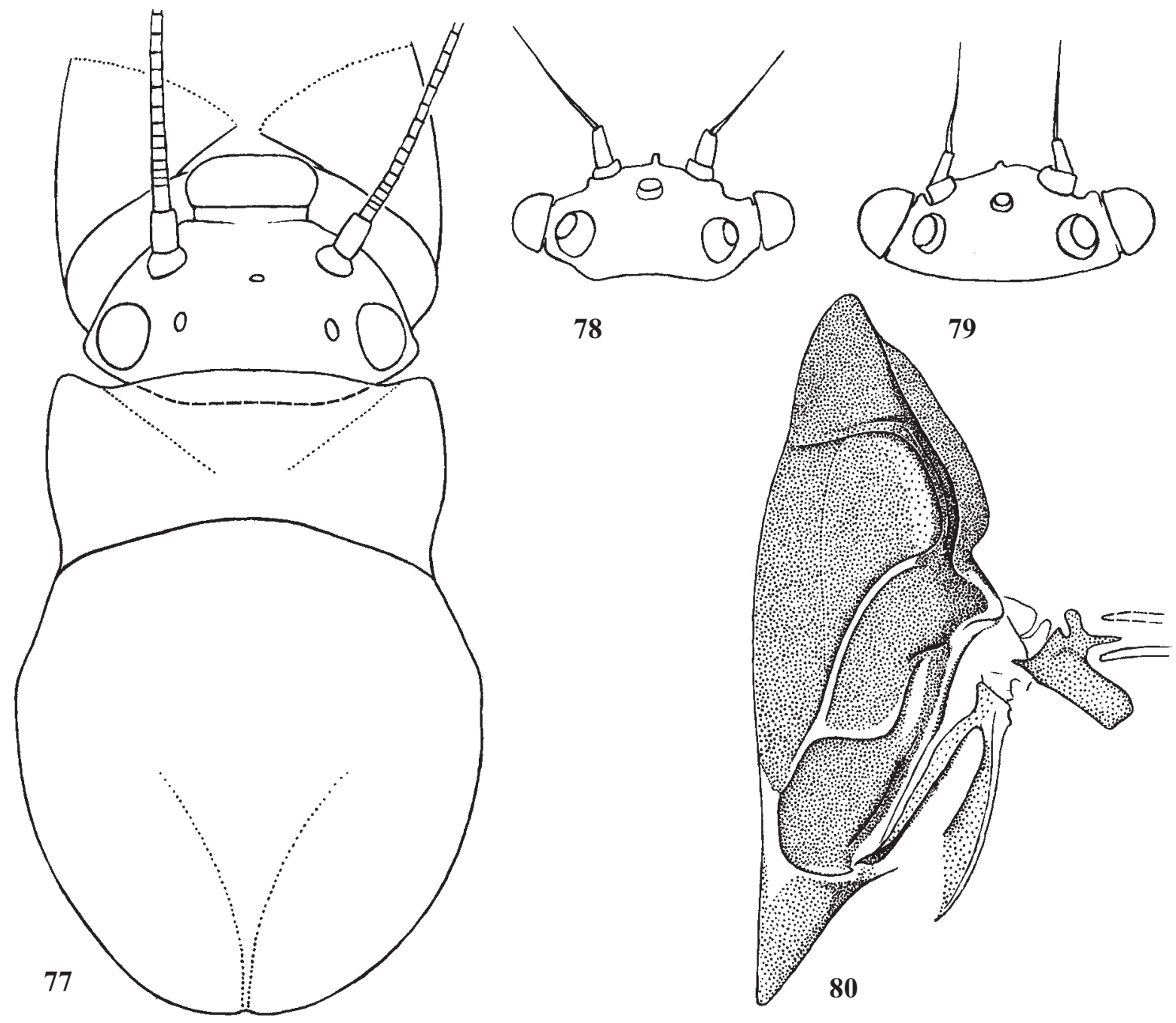

Figs 77-80. Tricorythus (Sparsorythus) celebensis sp.n.: 77 — head, pronotum and mesonotum of last instar male larva; 78 - head of male imago; 79 - head of female adult; 80 — right half of subimaginal exuviae of male mesonotum (brown cuticular pigmentation shown by dots).

Рис. 77-80. Tricorythus (Sparsorythus) celebensis sp.n.: 77 - голова, пронотум и мезонотум личинки самца последнего возраста; 78 - голова самца имаго; 79 - голова взрослой самки; 80 - правая половина субимагинального экзувия мезонотума самца (пунктировкой показана бурая кутикулярная пигментация). 

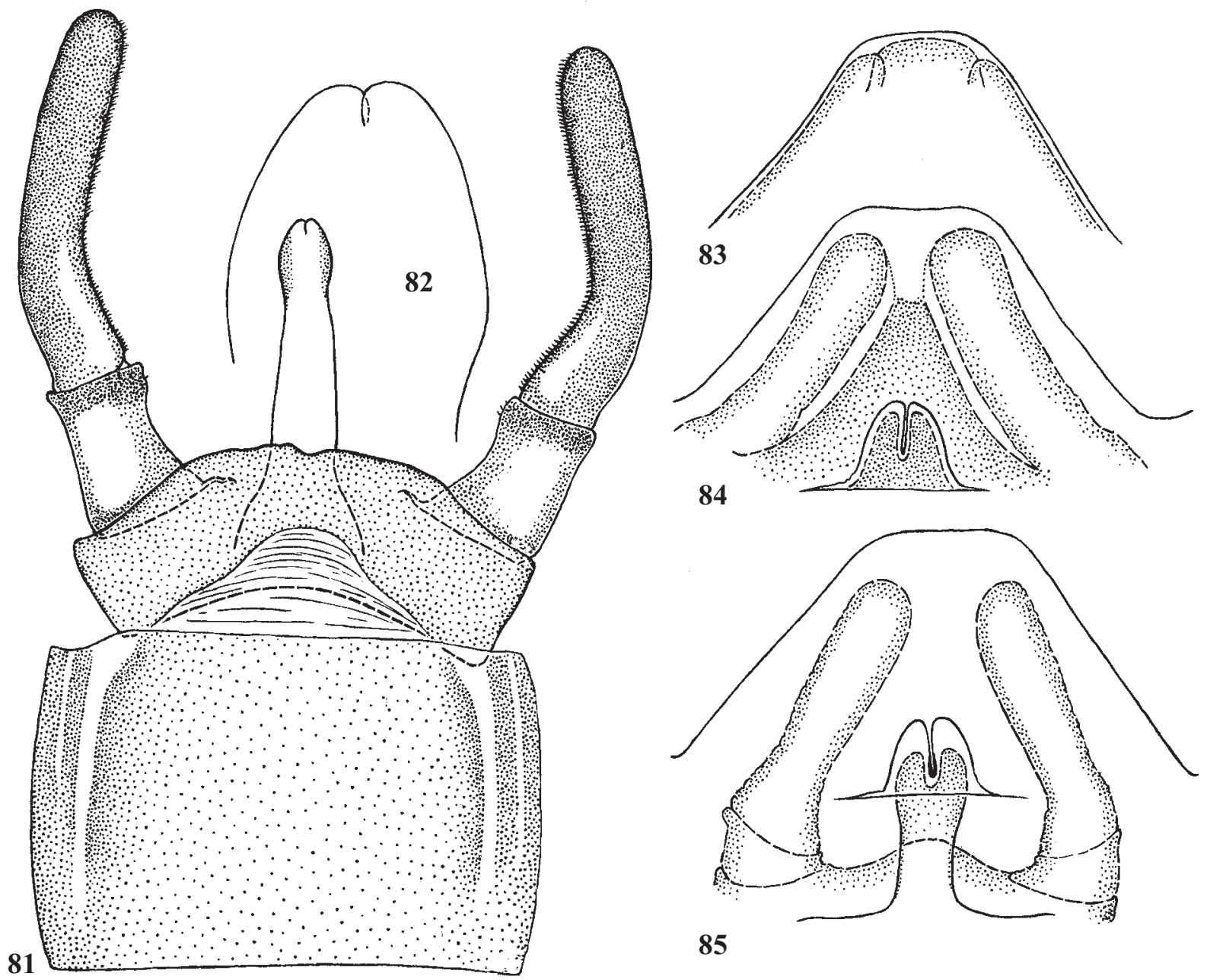

Figs 81-85. Tricorythus (Sparsorythus) celebensis sp.n., male genitals: 81 - genitals of imago, ventral view (gray hypodermal pigmentation shown by dots); 82 - apex of penis, enlarged; 83-85 - developing of genitals in last instar larva, dorsal view (larval cuticle shown by integral lines, tissues by interrupted line and dots).

Рис. 81-85. Tricorythus (Sparsorythus) celebensis sp.n., гениталии самца: 81 - гениталии имаго, вентрально (пунктировкой показана серая гиподермальная пигментация); 82 - вершина пениса, увеличено; 83-85 - гениталии, развивающиеся у личинки последнего возраста, дорсально (личиночная кутикула показана сплошной линией, ткани показаны прерывистой линией и пунктировкой).

oparapsidal suture and anterolateral scutal costa are darkest; sublateroscutum is dark; lateroscutum is dark, with a long blank; posterior scutal protuberances are dark (Fig. 80). Microtrichiae densely cover mesonotum except for posterior $2 / 3$ of sublateroscutum, most part of lateroscutum and whole posterior scutal protuberances; cuticle of posterior scutal protuberances bears sparse microtrichiae and prominent netlike relief (see Table). Basal plate of wing has distinctly outlined subimaginal sclerite of characteristic shape and light brown color (Fig. 80). Cuticle of legs is partly colorless, with intensive contrasting longitudinal stripes: each femur has four stripes along outer and inner margins; each tibia has brown basal part and stripe along outer margin; each tarsus in most part is brown. Cuticle of abdominal terga and sterna is light brown, with small, contrasting, paired blanks: each tergum II-IX has light median line, a pair of small submedian blanks near anterior margin, a pair of small sublateral blanks and one or two pairs of lateral blanks; each sternum II-VIII has submedian blanks in form of a pair of stripes diverging from anterior margin and a pair of dots behind them and two pairs of small lateral blanks; sternum IX is light, styliger darker. Gonostyli have dark band at joining of first and second segment. Cuticle of caudalii is colorless.

HyPODERMAL COLORATION: As in imago.

Imago, male. HYPODERMAL AND CUTICULAR COLORATION: Head and prothorax have intensive dark gray hypodermal maculation. Mesonotum has cuticle brown. Cuticle of mesolpeura is nearly colorless, through its gray hypodermal maculae are visible. On ventral side of pterothorax, the pair of episterna and the pair of furcasternal protuberances have cuticle light brown; median areas between them (i.e., basisternum and furcasternal impression) have cuticle colorless and hypoderm gray. Legs have intensive dark gray hypodermal coloration. Wings are dark gray. Abdominal terga and sterna look nearly unicolor thanks to intensive dark gray hypodermal pigmentation. Styliger, gonostyli and penis also have gray hypodermal pigmentation. Each segment of caudalii is dark gray proximally and colorless distally.

SHAPE: Eyes are small, stalked (Fig. 78). Genitals as in Figs 81-82: Sternum IX has well expressed dark lines, which 
border areas of attachment of sterno-styligeral muscles; these lines are longitudinal, nearly straight and parallel-sided. Styliger has shape of a narrow ark: short, with length equal in middle and by sides, medially far extended from sternum IX. $1^{\text {st }}$ segment of gonostylus is relatively short. Penis is narrow, with slightly widened apical part, bifurcates at extreme apex, with apices brought together; in lateral view penis is slightly bent dorsally.
Development of male genitals. Larval protopenis has apical bifurcate part as long as that of protopenis of other species and longer than apical bifurcate part of adult penis of the same specimen. Proximal integral pat of larval protopenis is unusually short, shorter than that of other species; unlike it, proximal integral part of subimaginal and imaginal penis is long. During larval/subimaginal transformation apical bifurcate part of penis undergoes shortening, and proximal inte-

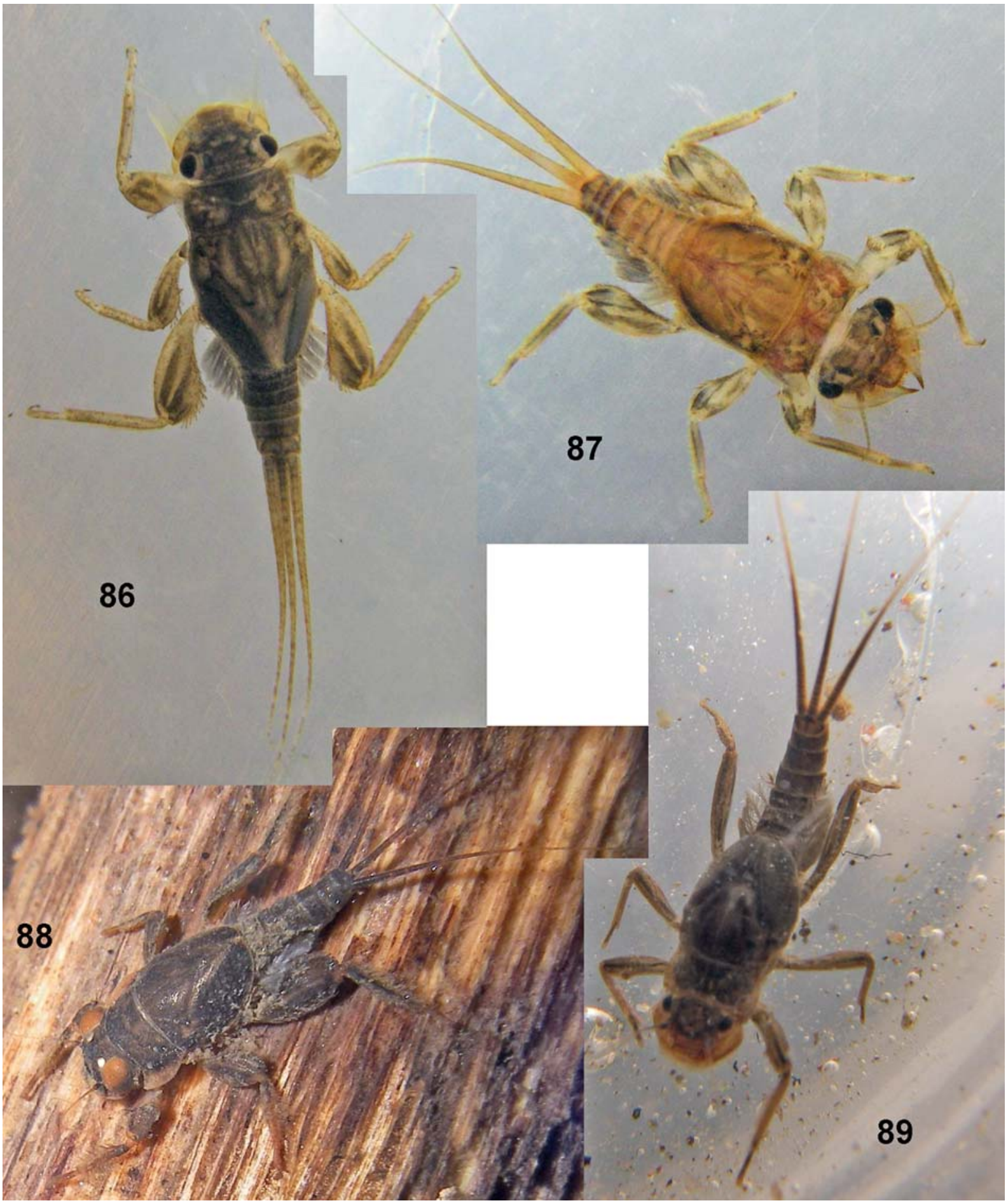

Figs 86-89. Mature male larvae of Tricorythus: 86 - T. varicauda; 87 - T. tinctus; $88-$ T. exophthalmus, sp.n.; $89-$ T. celebensis, sp.n. Рис. 86-89. Зрелые личинки самцов Tricorythus: 86 - T. varicauda; 87 - T. tinctus; 88 - T. exophthalmus, sp.n.; 89 - T. celebensis, sp.n. 
gral part undergoes more significant elongation than in other species (Figs 84-85); but, unlike T. tinctus, it elongates without inversion. Probably, features of genital structure and development are common for Sparsorythus, because in other species, for which male imagoes are described $[T$. (S.) bifurcatus, T. (S.) dongnai and T. (S.) multitabeculatus] genitals of male imago are similar to that of $T$. ( $S$.) celebensis.

Adult, female. Head as in Fig. 79. Cuticle has more intensive brown color of sclerites than in male subimago. Unlike male subimago, microtrichiae entirely cover sublateroscutum (see Table). Hypodermal coloration as in male. Femora are not wide, have the same width as in male subimago.

Egg. Pale yellowish, with polar cap of the same color. Surface with relief in a form of shallow convex net with large cells. Polar cap is shallow, as wide as egg [Sroka \& Soldan, 2008: Fig. 73).

DIMENSION. Wing length (and approximate body length) of male $7 \mathrm{~mm}$, of female $8 \mathrm{~mm}$.

COMPARISON. Larva of $T$. (S.) celebensis has femora less wide than in most Tricorythus; among Sparsorythus, similar proportions of larval femora are described only for $T$. $(S$.) gracilis from India. $T$. (S.) gracilis differs from all other species by elongation of setae on lateral sides of paracercus and inner sides of cerci. Unlike it, $T$. $(S$.) celebensis has equally small spine-like setae on all sides of cerci and paracercus. Imago of $T$. (S.) celebensis differs from $T$. $(S$. bifurcatus, $T$. (S.) dongnai and T. (S.) multitabeculatus by eyes of male, which are as small as in female, and by uniformly dark color of wings.

EMERGENCE. Adults were reared from larvae collected in a mountain stream - tributary of river Mamasa. But they were most abundant in the river Mamasa itself, just in the town Mamasa, where this species dominates. Larvae molted to adults only at the beginning of darkness. Male subimagoes molted to imagoes during the same night. Female adults dropped eggs just after larval/subimaginal molt. The fact that females have no subimaginal/imaginal molt, is supported by the fact that female adults have subimaginal microtrichiae on wings and at the same time their claws do not contain imaginal claws; unlike them, claws of male subimago contain imaginal claws during whole subimaginal development and earlier, before larval/subimaginal molt.

Tricorythus (?Sparsorythus) ?jacobsoni Ulmer, 1913

MATERIAL. INDONESIA, JAWA, $30 \mathrm{~km}$ SE Bogor, Cipanas, 25.II.2008, coll. V. Ivanov: $1+$ adult.

Adult, female. Body and legs have intensive dark gray hypodermal pigmentation. Wings are uniformly dark gray. Wing length $8 \mathrm{~mm}$. The fact that female has no subimaginal/ imaginal molt, is supported by the fact that the female adult has subimaginal microtrichiae on wings and at the same time its claws do not contain imaginal claws.

\section{Tricorythus (?Sparsorythus) sp. B}

MATERIAL. INDONESIA, JAWA, Bogor, botanic garden, 24.II.2008, coll. V. Ivanov: 1 adult.

Adult, female. Body and legs have intensive dark gray hypodermal pigmentation. Femora of all legs are unusually thick and muscular; in this respect it differs from other species examined, whose femora can be wider or narrower, but always flattened, twisted and having weak muscles. Wings are dark in proximal half and light in distal half. Wing length $6.5 \mathrm{~mm}$. The fact that female has no subimaginal/imaginal molt, is supported by the fact that the female adult has subimaginal microtrichiae on wings and at the same time its claws do not contain imaginal claws.
ACKNOWLEDGEMENTS. This investigation was supported by the Russian Federal Program on Support of Leading Scientific Schools, grant No. 963.2008.4. The author thanks Pavel Sroka for important information about Sparsorythus and Helen Barber-James for material on T. discolor and discussion.

\section{References}

Barber-James H.M. 2008. A synopsis of the Afrotropical Tricorythidae // F.R. Hauer, J.A. Stanford \& R.L. Newell (eds.). International advances in the ecology, zoogeography and systematics of mayflies and stoneflies. // University of California Publications in Entomology. Vol.128 (Proceedings of the 11 International Conference on Ephemeroptera, Montana, USA, 22-29 August 2004). P.187-203.

Barnard K.H. 1932. South African May-flies (Ephemeroptera) // Transactions of the Royal Society of South Africa. Vol.20. P.201-259.

Corbet P.S. 1960. Larvae of certain East African Ephemeroptera // Revue de Zoologie et Botanique Africaines. Vol.61. P.119-129.

Demoulin G. 1954. Recherches critiques sur les Ephéméroptères Tricorythidae d'Afrique et d'Asie // Bulletin et Annales de la Société Entomologique de Belgique. Vol.90. N.9-10. P.264-277.

Eaton A.E. 1868. An outline of a re-arrangement of the genera of Ephemeridae//Entomologist's Monthly Magazine. Vol.5. P.8291.

Eaton A.E. 1871. A monograph on the Ephemeridae // Transactions of the Entomological Society of London. P.1-164. P1.1-6.

Eaton A.E. 1883-1888. A revisional monograph of recent Ephemeridae or mayflies // Transactions of the Linnean Society of London (2). Vol.3. P.1-352. P1.1-65.

Elouard J.-M. \& Oliarinony R. 1997. Biodiversité aquatique de Madagascar. 6. - Madecassorythus un nouveau génre de Tricorythidae definissant la nouvelle sous-famille des Madecassorythinae (Ephemeroptera Pannota) // Bulletin de la Société entomologique de France. T.102. No.3. P.225-232.

Kimmins D.E. 1956. New species of Ephemeroptera from Uganda // Bulletin of the British Museum (Natural History). Entomology. Vol.4. No.2. P.71-87.

Kimmins D.E. 1960. Notes on East African Ephemeroptera with descriptions of new species // Bulletin of the British Museum (Natural History). Entomology. Vol.9. No.6. P.337-355.

Kluge N.J. 2004. The phylogenetic system of Ephemeroptera. Kluwer Academic Publishers. 456 pp.

Kluge N.J. 2007. Oligoneuria itayana sp.n. (Ephemeroptera, Oligoneuriidae) - a new mayfly species from Peruvian Amazonia // Russian Entomological Journal. Vol.16. No.2. P.127-137.

Lestage J.-A. 1942. Contribution à l'étude des Ephéméroptères. XXV. - Notes critiques sur les anciens Caenidiens d'Afrique et sur l'independance de l'evolution tricorythido-caenidienne // Bulletin du Musée Roual d'Histoire Naturelle de Belgique. T.18. No.48. P.1-20.

Navás L. 1926. Algunos insectos del Museo de Paris. 3. ${ }^{a}$ Serie // Brotéria (Série Zoológica). T.23. P.95-115.

Navás L. 1936. Insectes du Congo Belge. Serie IX // Revue de Zoologie et Botanique Africaines. T.28. P.333-368.

Oliarinony R. \& Elouard J.-M. 1997. Biodiversité aquatique de Madagascar: 7 - Ranorythus, un nouveau génre de Tricorythidae définissant la nouvelle sous-famille der Ranorythinae (Ephemeroptera, Pannota)// Bulletin de la Société entomologique de France. T.102. No.5. P.439-447.

Oliarinony R., Elouard J.-M. \& Raberiaka N. 1998a. Biodiversité aquatigue de Madagascar: 8 - Spinirythus, un nouveau génre de Tricorythidae (Ephemeroptera Pannota) // Bulletin de la Société entomologique de France. T.103. No.3. P.237-244.

Oliarinony R., Elouard J.-M. \& Raberiaka N. 1998b. Biodiversité aquatigue de Madagascar: 9 - neuf nouvelles espèces de Tricorythus Eaton [Ephemeroptera, Pannota, Tricorythidae] // Revue français d'entomologie (N.S.). T.20. No.3. P.73-90. 
Oliarinony R. \& Sartori M. \& Elouard J.-M. 2000. Première description des larves et des oeufs du malgache Madecassorythus (Ephemeroptera, Tricorythidae) // Mitteilungen der Schweizerischen Entomologischen Gesellschaft. T.73. No.3 4. P.369-378.

Pictet F.J. 1843-1845. Histoire naturelle générale et particulaire des Insectes Névroptères - Famille des Ephemerines. Baillière édit., Paris (Kessmann et Cherbuliez édit., aussi à Genève). 319 pp., 47 tabs.

Savigny J.-C. 1826-1827. Explication sommaire des planches d'insectes de l'Egypte et de la Syrie // Description de l'Egypte, ou recueil des observations et des recherches qui ont éte faites en Egypte pendant l'expedition de l'armee Française. Second edition, dédiéé au roi publiée par C.L.F. Panckoucke. T.10 (1826). P.110. Pl.2 (figures). T.22 (1827). P.431-458 (text)
Sroka P. \& Soldán T. 2008. The Tricorythidae of the Oriental Region // F.R. Hauer, J.A. Stanford \& R.L. Newell (eds). International advances in the ecology, zoogeography and systematics of mayflies and stoneflies. University of California Publications in Entomology 128 (Proceedings of the 11 International Conference on Ephemeroptera, Montana, USA 22-29 August 2004). P.313-354.

Ulmer G. 1913. Ephemeriden aus Java, gesammelt von Edw. Jacobson // Notes from the Leyden Museum. Vol.35. P.102-120.

Ulmer G. 1916. Ephemeropteren von Äquatorial-Afrika// Archiv für Naturgeschichte (A) (1915). Bd.81. Nr.7. S.1-19.

Ulmer G. 1921. Über einige Ephemeropteren-Typen älterer Autoren // Archiv für Naturgeschichte (A). Bd.87. Nr.6. S.229-267.

Ulmer G. 1930. Entomological expedition to Abyssinia, 1926-27; Trichoptera and Ephemeroptera // Annals and Magazine of Natural History. Ser.10. Vol.6. P.479-511. 